\title{
The Roman Towns in the Valley of the Bætis, between Cordoba and Seville
}

\author{
the Rev. W. G. Clark Maxwell M.A.
}

To cite this article: the Rev. W. G. Clark Maxwell M.A. (1899) The Roman Towns in the Valley of the Bætis, between Cordoba and Seville, Archaeological Journal, 56:1, 245-305, DOI: 10.1080/00665983.1899.10852825

To link to this article: http://dx.doi.org/10.1080/00665983.1899.10852825

\section{Published online: 16 Jul 2014.}

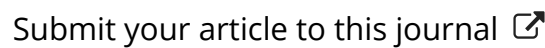

Џll Article views: 2 
THE ROMAN TOWNS IN THE VALLEY OF THE BETIS, BETWEEN CORDOBA AND SEVILLE.

By the Rev. W. G. CLARK MAXWELL, M.A.

\section{Preface.}

The exploration, excavations, \&c., mentioned in the following paper were undertaken during the months December, 1889-April, 1890, in the valley of the Guadalquivir. The Trustees of the Craven Fund at Cambridge made a grant of $₫ 80$ for excavations, \&c., in this part of the world. The smallness of the sum in proportion to the size of the area taken in hand made it necessary to employ but few workmen-at Penaflor four; at Peña-de-la-Sal, first two and then four; at Alcolea three. Mr. Bonsor, the discoverer and excavator of the Necropolis of Carmona, accompanied me, and his ready help and practical acquaintance with the country were, of course, invaluable.

The method pursued by us was as follows:-We determined to make a careful personal inspection of both banks of the river, usually in company, and almost always on foot. In spots where remains appeared specially abundant, and where we could obtain the owner's permission, we made trial trenches and in one or two instances somewhat more extended investigations, but anything like systematic excavation of a site was rendered out of the question by the lack of means at our disposal.

\section{INTRODUCTION.}

Between Cordoba and Seville is a stretch of 120 English miles of the Guadalquivir, in which we find record from Pliny and other ancient authors of ten Roman cities-.Carbula, Detuma (or Decuma), Celti, Axati, Arva, Canana, Oducia, Næva, Ilipa, and Ítalica. The progress of the centuries has entirely obliterated some (e.g., Oducia and Arva) and much diminished the importance of others. Only one at the present day can at all lay claim to the 
title of town, and one post-Roman town, Palma del Rio. lias grown up. The reasons for this decline are not very plain; the almost constant state of war in which the south of Spain was involved from the time of the invasion of the Vandals, followed by that of the Goths (c. 400) down to the final expulsion of the Moors from this part about 1280, may account for much destruction and more decay. In an age of plundering warfare, as was that which preceded the "Reconquista," the sites suitable for commerce, but exposed to attack, which the Romans had occupied, were gradually abandoned for natural strongholds in the spurs of the Sierra Morena; and the chief memorials of the Moorish occupation are the square keeps, which served as towers of refuge for the travellers from town to town, and which bear a strange resemblance to the peels of the Scottish Border.

The campaigns of Ferdinand the Saint brought a measure of peace, which was perhaps after all but exhaustion, to the valley of the Guadalquivir. The energies of Spanish chivalry were henceforth directed to the final expulsion of the infidel, and commerce and the internal development of the country were neglected for this more important end. Simultaneously with the capture of Granada came the discovery of the New World. The energy and enterprise of Spain were diverted into this fresh channel, and the Guadilquivir was finally abandoned as a water-way and an important means of inland communication. Man's imprudent destruction has completed what the neglect of man had begun; the forests with which the Sierras of Spain were anciently clothed have been cut down and converted into charcoal, without replanting to remedy the deficiency. For this reason the rainfall is now insulficient and uncertain; the noble river is encumbered with shoals and weirs, and has a stream insufficient for commerce, except when rolling down in destructive flood, sweeping away bridges, cutting out new courses for itself in the rich alluvial plain, and carrying down to the sea thousands of tons of fertile soil.

All this must have presented a very different appearance during the long ages of peace which the country enjoyed under the Roman rule. At every step along the banks of the river the traveller comes across some trace of their 
careful and enlightened system of agriculture and irrigation. Here it is a river wall of concrete to restrain the river from encroaching on a now vanished town; there a series of tanks, now empty, broken and useless, which formerly collected the surface-water or drainage from the hills and stored it, up, to provide against the possibility of drought; there again, the ruined and disused conduit of an aqueduct which conveyed water from an abundant spring to the town, sometimes six miles distant, on the banks of the river. At very frequent intervals, too, we find the traces of one of the Roman villages or "latifundia," where the soil is thick with fragments and handles of amphoræ, tiles, tesseræ of mosaic, and the fragments of the marble lining which once decorated the rooms of the more distinguished inhabitants. On the outskirts of some wretched village, such as Santiponce (Italica), or a place of somewhat greater importance, as Alcala del Rio (Ilipa), or a city like Carmona (Carmo), we find the circuit of the Roman wall now enclosing olive-yards and cornfields, while the modern houses of tapia or sun-dried mud are supported by hewn Roman stones stolen from the ruins of a neighbouring amphitheatre or mausoleum. The marble columns which once adorned some public edifice now serve as the threshold of a iabourer's cottage, while the pedestal which records the erection of a gilded statue of a public official by the municipium which he had benefited forms part of the floor, mingled with pieces of tessellated pavement and bricks of all sizes and dates. The owners themselves, in most cases, care nothing for the objects in their possession, and only begin to feel an interest in them when they see the explorer's note-book produced, an interest which speedily grows to devotion if they see the remotest possibility of an offer of purchase. Local science or enthusiasm has as yet done little for the preservation and systematic investigation of the remains of antiquity which occur so thickly in their midst; and those who have occupied themselves with the ancient topography of Bxtica have for the most part contented themselves with tracing resemblances, fanciful and unscientific, between ancient and modern names, and thus identifying places which often have never had any connection with each other. There are, however, honourable 
exceptions, notably in the case of the early members of the Academia Sevillana, who were diligent and painstaking investigators, under conditions much less favourable than those which surround the explorer of the present dav.

The noble work done by Dr. Emil Hiibuer in Vol. II of the Corpus Inscriptionum Latinarum is of the very greatest use, and a comparison of the inscriptions which he reports as extant at a locality with those that are to be found there now shows how immeasurably we should be the poorer had that work not been undertaken. But it could not reasonably be expected that in the course of so short a time as Hiibner devoted to the compilation of so bulky a volume he should have been able to visit each and every locality from which he records inscriptions; thus we find that in many cases where he did not personally copy the inscription certain mistakes in the Corpus Inscriptionum Latinarum may be detected, and of course other inscriptions have since been brought to light, which have not yet found their way into the supplements published in the Ephemeris Epigraphica. Thus even in that branch of Spanish archæology which Hiibner has specially made his own, it is possible in some degree to supplement his work.

With regard to topography, as mentioned above, hardly any work of real value has been accomplished. Owing to the unfortunate preference for study over field work, many of the proposed sites and identifications are hopelessly incorrect and misleading. Such conclusions as we have ventured to suggest in the pages which follow will be found, I think, to be based upon observed phenomena, and worthy of at least serious consideration.

The books chiefly consulted have been these:-

Hubner. Vol II of the Corpus Inscriptionum Latinarum.

His Arqueologia de Espana (Barcelona, 1888, 8vo). A most valuable work, giving a complete account of the science of archæology in Spain up to the present, with a full list of authorities, and bibliography.

An Article by Dressel in the Annali dell' Instituto, Vol. L, 1878, p. 118. ff. on the excavations carried out by him in the Mte Testaccio at Rome. He comes to the conclusion that most of the stamps which he there found on the handles of amphoræ are of Spanish or African origin, and in fact, we have been able to confirm this conclusion with additional eridence, by the list which is given in the Appendix of the stamps collected by us. 
There is also a good deal of information to be gathered from the Memorias de la Acadernia Sevillana, Vol. I (the only one published), 1773 , as regards the sites of Axati, Arva, and Munigua.

An Article by Detlefsen in the Philologus, Vol. XXX, 1870, p. 265 f. on "Die Geographie der Provinz Batica bei Plinius," which contains many useful suggestions as to the classification and status of the various towns.

Roman Remains on tue Banks of the Guadalquivik between Cordoba and Penaflor.

\section{Right Bank, as far as Almodovar.}

April 13th. As soon as we were free of the outskirts of the town, we followed the margin of the river, wherever practicable, but where we saw an old bed of the stream, we preferred that, as experience taught us that such was the most likely place in which to find a Roman "despoblado," or land now waste but showing signs of former occupation. There are various degrees of despoblado. (1) "Tierra de Villar," where the ground contains potsherds, tiles, \&c. This we have indicated in the map with $\square$ in red. (2) When such a spot has such masses of fragments of amphoræ, \&c., or many handles bearing the same stamp, as to suggest the debris of a potter's kiln, even if such have not actually been found we have used this mark $\mathrm{w}$. (3) Where the remains are of such extent, or contain so many fragments of walls or cisterns, as to suggest a larger settlement, a latifundium or centuria, we have marked it thus

The first site which we come upon on this side is near the farm of Hacienda del Castillo, about 7 kil. from Cordoba. Here there are two or three cisterns at somewhat wide intervals, one of them, of which only one side remains perfect, measuring $4.80 \mathrm{~m}$. in length, 1.15 in height, the walls 55 thick, being coated in the interior with (1) a thick layer of pounded brick and lime, (2) a thinner skin of lime and fine sand. The corners are finished with a roll moulding, originally designed to prevent leakage. The sides are of concrete.

The next Roman site is at some distance, being fully 
12 kil. down stream ; on the way, a good many bricks, \&c., are seen here and there, but so widely scattered, and so sparsely, that we do not feel justified in placing at any particular spot the mark of a despoblado. At El Molino, however, where there is a mill turned by the stream Guadaroman, there is a large collection of debris on a height between that stream and the river. There are traces of an aqueduct which apparently supplied this spot, which is crossed by the railway between Almodovar and Cordoba.

The next site of any note is at La Tejera, about $6 \mathrm{kil}$. farther on, and this time not quite on the river, but on a small stream of that name. (The site has no special name, hence in such a case we give the name of the stream, or of some natural object near.) The remains here are slight-a few squared stones, evidently Roman, and the usual potsherds, tiles, \&c.

Another $1 \frac{1}{2}$ kil. brings us to Almodovar.

II. Left Bank, as far as Almodovar.

April 15th. Soon after leaving Cordoba, we cross the stream of La Miel, with a small despoblado, but not more than tierra de villar is to be noticed. Four kil. farther on, on the west slope of a hill which overhangs the river, is Las Casillas, with tierra de villar, and a strong spring enclosed in a well house, which may have some remains of Roman work, but it was not possible to be certain. We next pass the river Guadajoz, and follow the river bank for about 5 kil., when we come to the site of $L a$ Reina, which shows signs of Roman occupation, and where a handle with the mark $A \cdot$.FER was picked up. There now follows a long stretch of bank unmarked by any decided signs of habitation, a large portion of it being "land which the rivers have spoiled," and we only reach unequivocal Roman remains at El Sotillo, $17 \mathrm{kil}$. farther down. Here there is much tierra de villar and fragments of wall projecting from the face of the bank. These walls are constructed, as commonly in this part, of potsherds, the interstices being filled either with earth or mortar. This makes a very strong wall, and must have cost but little for materials in a country where pottery was so abundant and to all appearance so extensively made. (See illustration of wall at La Botica, 
To face page 251.

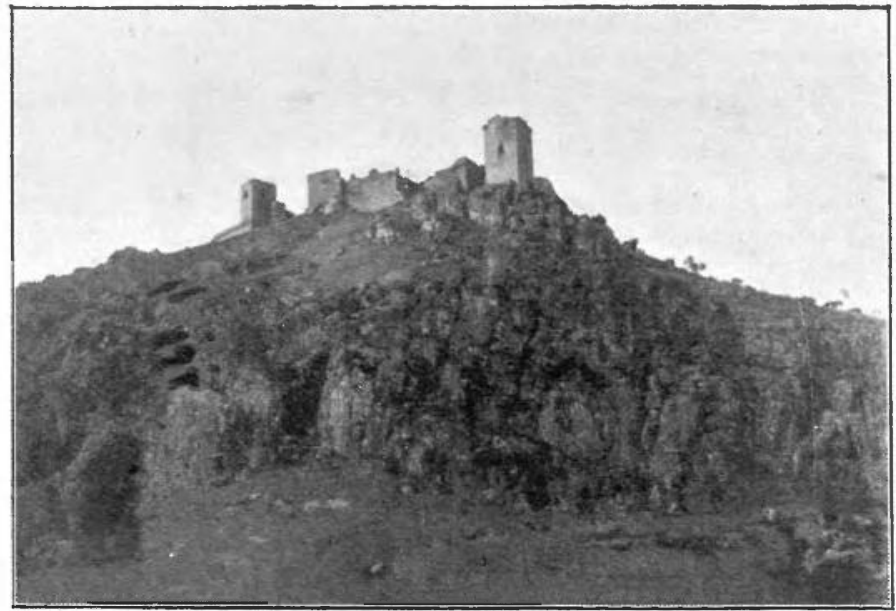

ALMODOVAR CASTLE FROM THE SOUTH-WEST.

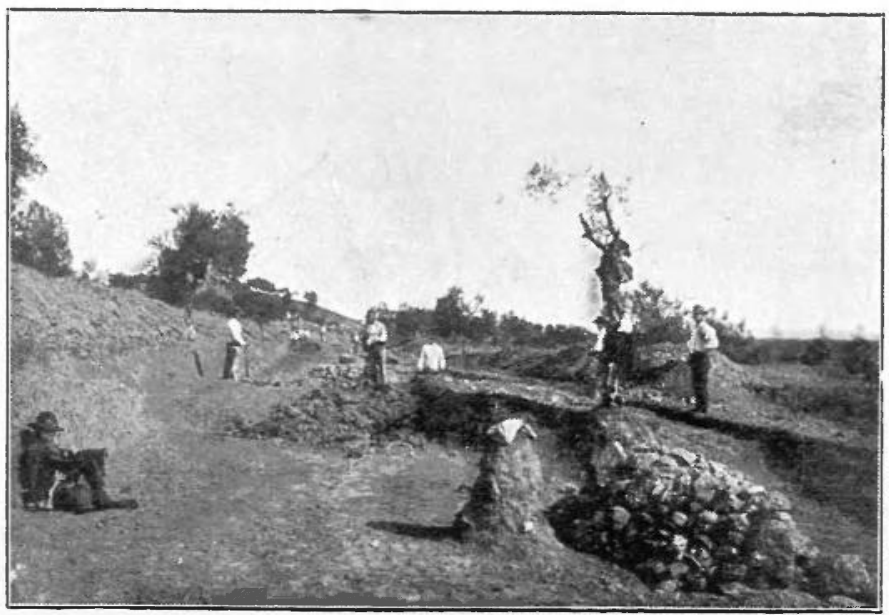

PENA DE LA SAL. PLACE WHERE THE TOMBS WRRE FOUND. 
Penaflor, where amphora-necks are also inserted into the wall.)

At about 5 kil. distance is La Barqueta, where there is besides the ordinary tierra de villar a large cistern of the ordinary kind, measuring $21 \mathrm{~m}$. in length by $8.80-$ depth unobtainable for the earth. The concrete walls are $\cdot 75$ in thickness. Three other smaller cisterns are broken and fallen by the action of the current on the bank in which they stood. A very short distance now brings one to Almodovar.

\section{Carbvla.}

With regard to the identification of this site, it must be admitted that we have but slight evidence to go upon. Inscriptions are not very satisfactory in this case, the only one with local bearing having been found in Almodovar ${ }^{1}$ at the end of the last century. It consists of a dedication to Vespasian and his sons, dated A.D. 74.

IMP $\cdot$ CAES $\cdot$ VESPASIANO $\cdot$ AVG PONTIF $\cdot$ MAX $\cdot$ TRIBVNIC $\cdot$ POTEST

$\mathrm{V} \cdot \mathrm{IMPERATORI} \cdot \mathrm{XI} \cdot \mathrm{P} \cdot \mathrm{P} \cdot \mathrm{COS} \cdot \mathrm{V} \cdot \mathrm{DES} \cdot \mathrm{VI}$ CENSORI $\cdot$ LIBERISQVE $\cdot$ EIVS

PAGANI - PAGI - CARBVLENSIS

The two others from this district given by Hübner are merely funeral tituli, and furnish no information. ${ }^{2}$

In default, then, of evidence to the contrary, Carbula may most naturally be placed in Almodovar, and an examination of the ground tends to favour this view. Almodovar is built on the east slope of a large spur of limestone rock which strikes south from the outskirts of the Sierra Morena and ends in an imposing cliff 400 to 500 feet above the river, on the summit of which is placed the Castle of Pedro of Castile. ${ }^{3}$ It is a natural stronghold, and completely commands the road from Cordoba along the right bank of the river, and hence has always been considered as one of the keys of Andalucia. The Moorish name which it bears leads us to suppose that they did not neglect the great natural advantages of the situation. Is it too much to suppose that the first syllable

1 C.I.L., II, 2322.

2 $I b ., 2323,2324$.

3 See photograph No. 1. 
CAR in Carbula has reference to the same magnificent fortress? ( $C f$. Car-mona, Granada (Karnatta), Cor-doba? \&c.)

The splendid castle which now crowns the summit of the hill of Almodovar has nothing distinctively Romanthe main fabric is, as stated above, of the time of D. Pedro (1369-79), with certain additions, apparently of the 15th century. The substructures of the castle walls, however, are older than the building above them, and appear to be of Moorish work, since they much resemble some of the masonry to be seen in the Moorish walls of Cordoba, in the south-west angle of the city near the Palace of the Archbishop. After so many additions and alterations, it is not wonderful that the original Roman building, if there ever was any, should have been so completely removed or concealed. In the town itself there are to be scen, as in almost every other town of this district, a considerable number of squared Roman stones, which now serve either for the corners of houses or for protecting the corners of the streets from damage by vehicles. There are also some fragments of marble columns, but on such slight indications one cannot build anything certain, since the Spaniard will frequently go five miles to fetch a stone, rather than cut it at his own door.

The ground, too, shows signs of Roman occupation, though not to the same extent as many to which allusion will be made subsequently.

These various signs, taken together, seem to indicate that there was not a very large Roman town here, if this was the site of Carbula. Yet this same town was of sufficient importance to strike its own coins, ${ }^{1}$ and that, too, at a short distance of the capital, Cordoba. ${ }^{2}$ May we conclude that its importance was due to its strength as a position, rather than for any trade facility which it offered?

We visited in the neighbourhood of Almodovar, on March 31st, some quarries which appear, from the method

1 Coins of Carbula, Eckhel, I, 16. Delgado, Nuevo Metodo, \&c., I, 52, Pl. VII.
2 A careful surrey of the river bank for a considerable distance, both abore and below Almodovar, failed to bring to light ary remains of large settlement. 
employed in cutting the stone, to be of Roman foundation; but subsequent work has so much altered the quarries in most places, that the evidence is not very clear.

III. Right Bank, from Almodovar to Posadas.

March 31st. A short distance from the town there is to be seen a wall of concrete barring a small valley, probably intended to act as a reservoir. A little farther un is La Casilla, where there is some extent of tierra de villar. Near the mouth of the Guadiato, however, and on the bank of that stream, is a large despoblado, which we have named after the river. Here there are great collections of potters' debris, proving that this was a pottery. Six stamps which we found here all bore the same $\mathbf{C} \cdot \mathrm{IVBAR}$. There also appear to be the remains of concrete reservoirs.

Crossing the Guadiato by a fine 15th-century bridge, and passing a portion of bank at a considerable elevation above the river, we come to La Torre Cabrilla, a 14thcentury tower of refuge, situated about halfway between Almodovar and Posadas. Just beyond this is a despoblado of the same name between the streams La Cabrilla and Gualbaida, chiefly remarkable for a face of wall $25.50 \mathrm{~m}$. long and 3 high, made of alternate bands of brick and river-stones. Just beyond the Gualbaida is another despoblado, to which we have given the name of the stream; here is much debris of pottery, but no stamps were obtained. Just before reaching Posadas we came across extensive remains of reservoirs, \&c., one of which was apparently vaulted in two stories, though but little now is left of it. It is probable that we have here the remains of the ancient Detuma or Decuma, all squared stones, \&c., having been long ago removed for use in more modern buildings.

IV. Left Bank, from Almodovar to Posadas.

March 31st. The bank for some little way is much altered from its original course, and is flat, sandy, and overgrown with tamarisk, \&c. The first signs of Roman occupation are to be seen at Villaseca, near the mouth of the Guadalmozan, and on the bank of the old course of the river. Here are large quantities of potsherds, and the abundance of clay here suggests a pottery. Here two marks were picked up, but so badly preserved as to be 
almost illegible. Continuing to descend the river, we find that the old bank diverges to the south of the present course. Nothing, however, is to be observed on either till they reunite at $L a$ Estrella, where there is much tierra de villar and some imperfect cisterns. This is also situated near a modern farm, on the stream whose name it bears, and which probably furnished the reason for its: first planting.

From this place to Posadas (11 kil.) is land which has been at various times the bed of the stream and thus. contains no sites.

\section{Detrma (Decrma).}

This is a town of some considerable uncertainty, both as to position and history. It occurs in the list given by Pliny, 3, 3, 10, as "Decuma" in the usual text.

In Ptolemy, it has the form $\Delta \eta r o v v \delta a$, or at least that word occurs in his list, in a position which corresponds very well. (Ptol. II, 4, 9.)

In any case, the town of Detuma or Decuma lies: between Carbula and Celti, which may be identified with certainty with the modern Penaflor. ${ }^{1}$ There are only two. sites between Cordoba and Penaflor which at all seem to show signs of considerable Roman occupation, such as would indicate the site of a town. These two sites are Posadas and Almodovar, and till further information is made available to locate them elsewhere, they may be considered respectively to represent Detuma and Carbula.

Meagre as was the information obtainable from inscriptions in the case of Carbula, we are still worse off in the matter of Detuma. Only one inscription, and that merely a funeral titulus, has come to light in the neighbuurhood of Posadas, and it gives us no local information whaterer. ${ }^{2}$

The name of Decuma or Detuma, too, is epigraphically unknown, and so far as our information serves us, there are nu coins of the town.

In the outskirts of Posadas and for a short distance up. the old course of the river (somewhat north of the present) are remains of concrete walls, apparently some founda- 
tions, but principally cisterns of various shapes and sizes, which probably served for water storage or deposition of sediment, the water being supplied from a rivulet which now runs through the centre of the town and away to the river. The ground here is not quite so full of potsherds as, for instance, at Peñaflor, but the signs of occupation are unequivocal, and Detuma may with considerable confidence be referred to Posadas.

V. Right bank, from Posadas to Penaflor.

March 31st. On the outskirts of the town there is to be seen the tower part of a Roman mill in the hedge at the right hand side of the road.

The first despoblado is to be found near the farm of Antonio Serrano, and is situated on an old bank of the stream, at some distance from the present bed. Here the tierra de villar is of great extent. There exist the remains of a large reservoir, and many amphora handles are to be noticed. Hence we got the following marks :

$$
\text { CVC ... (159) G. DEC (160) }
$$

Can the latter have some reference to Decuma? Compare the marks from sites just opposite this, Estrella de la Torrontera and Ia Dehesilla.

Four kilometres below this spot, near the stream of Moratalla, is another despoblado, which, however, was not so easily investigated, owing to the trees and undergrowth with which the site is covered. Here we found the mark:

\section{POEBI.}

We next arrive at Hornachuelos station on the railway. Here the river Bembezar is crossed by a now broken bridge of the 15 th century. Ten kilometres up this stream is situated the town of Hornachuelos, which we visited in the hope of finding Roman remains, but were unable to discover anything older than the Moorish occupation. There remains yet one arch (originally five) of a handsome Moorish bridge about a kilometre below the town.

Returning now to the river, we find after an interval the despoblado of Carrascal, where is a strong spring bubbling up among remains of concrete buildings which seem to have been a reservoir ; round about are fragments of pottery. At a very short distance, and about $\frac{1}{2}$ kil. from the river, is Mahoma, a small despoblado without 
anything to mark it beyond the usual tierra de villar. We then pass another stretch of river, arriving, just after crossing the modern road to Ecija from Palma station, at the Huerta de Belen, close to the sanctuary of that name. (March 19th.) Here the strong spring which serves to irrigate the fruit-garden attracted Roman cultivators and potters to settle, as is proved by the great quantities of debris of pottery, large and broken reservoirs, and walls constructed of potsherds in the manner formerly described. Among the marks on amphoræ collected here are :

FORTVNATM (146)

$\mathrm{F} \cdot \mathrm{S} \cdot \mathrm{F} \cdot \mathrm{A} \cdot \mathrm{QVA} \ldots(148)$

. . FERR EV¥ (150)
SX.FRCALV (147)

SAXoFERR (149)

... RATuT. (152)

Similar marks have been found in France.

We next pass the Retortillo by an ancient bridge. This probably formed the boundary between the conventus juridicus of Corduba and that of Hispalis, as it did till recently between the Provincia de Cordoba and that of Seville. Two kilometres farther on we come across a large and scattered despoblado at Cortijo de la Verja, and shortly to Peñaflor.

VI. Left Bank, Posadas to Penaflor.

April 1st. The first trace of Roman occupation is to be found at Caraola, where there is very little of the tierra de villar, usually so abundant, but a series of reservoirs on the slope of the low height which here bounds the valley, doubtless originally constructed to guard against a drought. Three of these cisterns measured respectively:

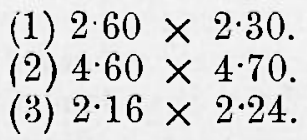

(In metres.)

The depth in no case could be exactly ascertained, as there was too great an accumulation of earth at the bottom.

We next come to La Estrella de la Torrontera, where there is much tierra de villar, at the beginning of the rise of the great barranco or cliff which here turns the current of the river. A kilometre farther on La Dehesilla. 
much remains of pottery; perhaps the site of kilns. Marks from these two places:

Est. de la T.

G DEC (164)

TVOว (166)

La Deh.

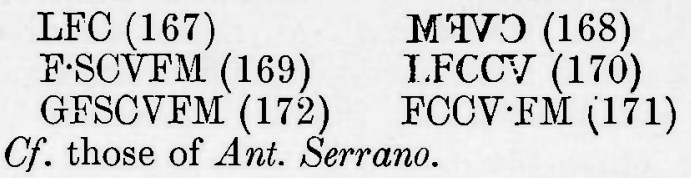

Arrived at the heights of the Torrontera del Picacho, we continue along them for some time, then descend, cross the arroyo Marruecos, and come to the farm of Las Monjas, where tierra de villar is to be seen, but nothing else of consequence. Following the old bank of the river south of its present course, we come in succession to La Choza (tierra de villar) and where the river once more occupies its old bed, to La Corregidora. Here there are traces of a settlement of somewhat more importance than those which we have hitherto been considering. The tierra de villar covers an area of 300 or 400 metres each way. There are ruins of walls, one piece measuring 20 metres in length by $\cdot 75$ in breadth, and several broken cisterns. Among the marks picked up here are:

FIGED
PPAEF $\widehat{\Psi}^{\prime}(173) \quad \begin{aligned} & \mathrm{OC} \\ & \mathrm{A}\end{aligned} \cdots(174) \quad[\mathrm{PM}$ incuse $(175)$

We next pass the arroyo Tamujo and approach a large rock which overhangs the stream and attracts attention, first, from the rarity of rock on this side of the river, and next from its remarkable shape, which strongly resembles a fortification and has doubtless suggested its name, Castillejo. On the farther side of this we find a despoblado, to which we have given the same name. Tierra de villar, amongst which we picked up this mark :

LFCCVF \& (176) Cf. those above.

Hence to Palma is a stretch of country containing, so far as we were able to discover, no certain traces of Roman settlement, with the exception of Cañuelos, a small 
despoblado with a spring and remains of some conduits which now irrigate a Huerta or orange garden.

March 19th. Palma itself, despite the classical origin sometimes claimed for it by local historians, has nothing to show in the way of Roman remains. We have indicated it in the map as tierra de villar, but this is somewhat a concession to popular clamour and a desire to avoid wounding the feelings of the Palmeños. Here we cross the Genil (Singilis) which perhaps was the boundary between the conventus of Corduba and Hispalis on this side of the river.

This is perhaps a suitable place in which to discuss a puzzling phrase in Pliny's Hist. Nat., 3, 3, 10. “Dextra Corduba . . inde primum navigabili Bæte; oppida Carbula, Decuma, fluvius Singilis, eodem Bætis latere incidens. Oppida Hispalensis conventus Celti, Axati, \&c."

The obvious meaning of this passage is that all the towns mentioned and the river Singilis are on the right or north bank of the stream, and in fact, we have given reason to show that Cordoba, Carbula, Decuma, Celti, Axati, \&c., are all on the north side; but the river Singilis, which beyond all doubt is the Genil, flows in from the south. How is this to be explained? For we can hardly say with (for instance) the Delphin editor of Pliny, 1826, "Dextro scilicet, et meridionali."

Some have maintained that Decuma must have been situated on the left bank, and sometimes place it in Palma; but though there is indeed little at Posadas, where we place it, there is less at Palma. The most considerable site between the Genil and Almodovar, on this side, is Torregidora, and there is certainly not sufficient evidence there to place a town of such size as to be mentioned in Pliny.

We are thus driven, unless we adopt the somewhat heroic course of writing "altero" or "ex adverso" for " eodem," to the conclusion that Pliny must have made a mistake; it is very possible that by the method of extracts which we know he employed, a phrase may have been inserted which destroyed the original connection of " eodem "with some previous entry referring to the left bank. Or, again, Pliny may simply have blundered.

March 29th. Seven kilometres up the Genil from Palma, 
or betwean ten and eleven from the Guadalquivir, is the despoblado of Malpica, which has one of the largest collections of fragments of amphoræ which we found in the course of this exploration. The heap forms a bank 10 metres and more high, on the bank of the Genil. Among the marks are the following:
$\mathrm{C} \cdot \mathrm{I} \cdot \mathrm{A} \cdot \mathrm{SA}(177)$.
$\mathrm{C} \cdot \mathrm{I} \cdot \mathrm{AL} \cdot \mathrm{B}(178)$
$\mathrm{C} \cdot \mathrm{I} \cdot \mathrm{A}(179)$
$\mathrm{C} \cdot \mathrm{I} \cdot \mathrm{A} \cdot \mathrm{FIA}(180)$
$\mathrm{C} \cdot \mathrm{I} \cdot \mathrm{A} \mathrm{L} \cdot \mathrm{B}(181)$
घЛАIIJ (182)
$\mathrm{G} \cdot \mathrm{I} \cdot \mathrm{A} \cdot \mathrm{B}(183)$
PAIC (184)
$\mathrm{Q} \cdot \mathrm{I} \cdot \mathrm{A}(185)$
QIL (187)
$\mathrm{Q} \cdot \mathrm{I} \cdot \mathrm{C} \cdot \mathrm{SEG}(188)$
टं' $\triangle \mathrm{I}$ О (186)
QIMEИ (190)
$\mathrm{Q} \cdot \mathrm{I} \cdot \mathrm{G} \cdot \mathrm{SEG}(189)$

May these last refer, possibly, to a Segovia in Bætica in this neighbourhood? (Cæsar d. B. Alex, c. 57, 6. Segoviam ad flumen Singiliense.)

March 19th. Between the mouth of the Genil and Penaflor are two despoblados, Huerta del Campillo and Cortijo del Portillo, neither of much importance. From the latter :

\section{VFNCEPA \\ CORALODFA}

Centri.

The case with the identification of Celti is considerably easier than that of Carbula or Decuma. That it was a place of distinction among its fellows of the river bank is indicated by the fact that it issued coins ${ }^{1}$ and was a station on the road from Obucula to Emerita. ${ }^{2}$ It was also a mark on the river, above which it was navigable only for boats of a shallower draught than those which plied below.

All this would lead us to expect considerable remains of the Roman town at some site on the river. This we find at Penaflor, where there are perhaps the most considerable remains between Cordoba and Italica. The mass of Cyciopean masonry, called by the natives the "Higueron," and many remains of dwellings, baths, pave-

\footnotetext{
1 Delgado. Nuevo Metodo de clasificacion de las monedas autonomas de España, Vol. I, p. 114, Pl. XTI. 2 Ib. Anton., 414, 5.
} 
ments, \&c., all testify to the former existence of a city of some considerable size. There are two inscriptions which bear upon the locality of Celti, both discorered in Peñaflor, but unfortunately neither of them extani.

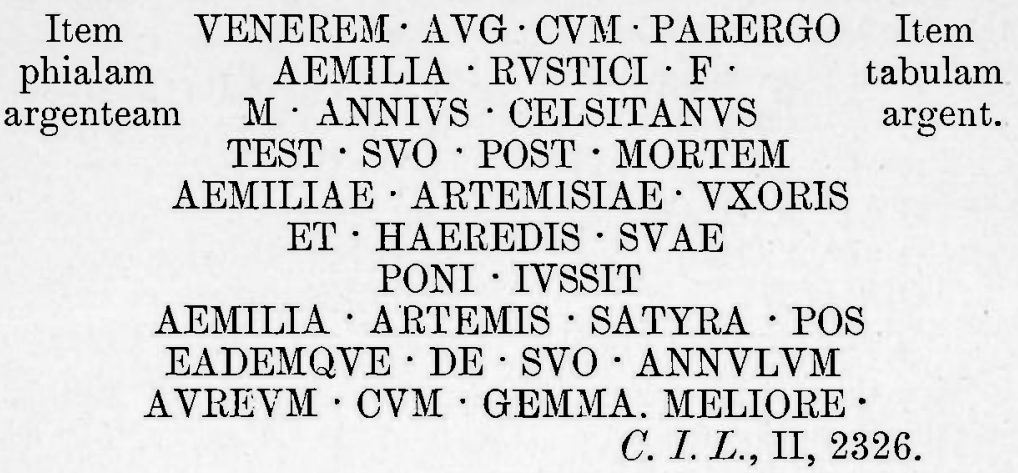

In this inscription we may notice the curious spelling, CELSITANVS for CELTITANVS. $C f$. the legends of the coins of Celti.

The other is an "inscription" on baked clay, POP as given by Bravo and repeated from him by Hübner, $C .1 . L .$, II, p. 321. A possible correction appears to be $|\mathrm{P} \cdot \mathrm{CI} \cdot \mathrm{CELT}| \mathrm{a}$ potter's stamp on amphora handles occurring in our experience at Peña de la Sal $(37,39,57$, of the list in the Appendix). If this be so, the value of such a stamp in determining iocality is considerably diminished, and we have but the one insertion first mentioned to help us. But there can hardly, I think, be any doubt as to the real position of Celti, and those who have placed it at Puebla de los Infantes or elsewhere ${ }^{1}$ must have done so without sufficient knowledge either of the written notices of Celti or of the present topography of Penaflor.

'The coinage of Celti, a considerable number of specimens of which have been found in and about Penaflor, is not very extensive, and nearly all the coins. bear as their distinctive type a wild boar on a spear. ${ }^{2}$

1 P. de los Infantes. Eckhel. Doctr. Numoram, I, 18; Ukert; Sestini. 
To face page 261.

PLAX 1.
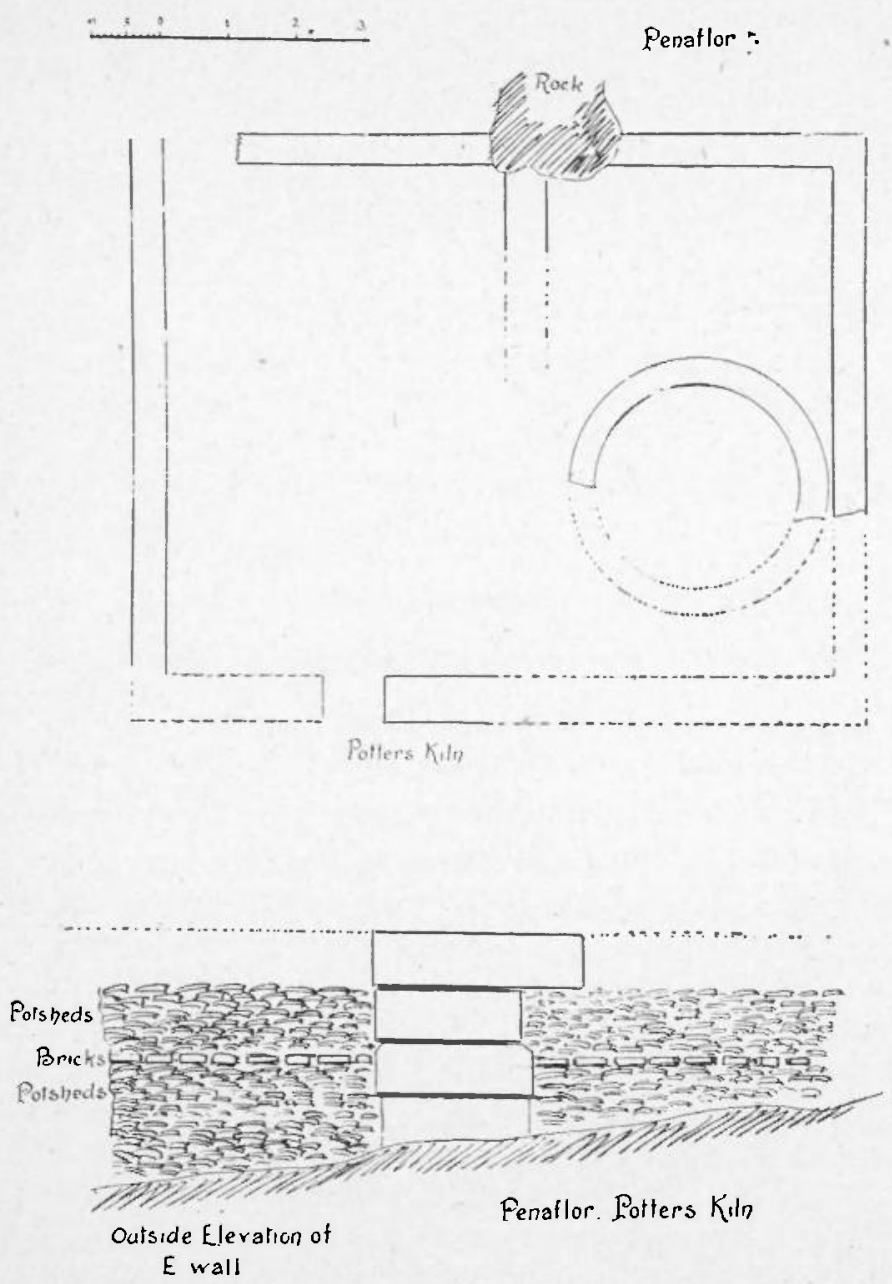


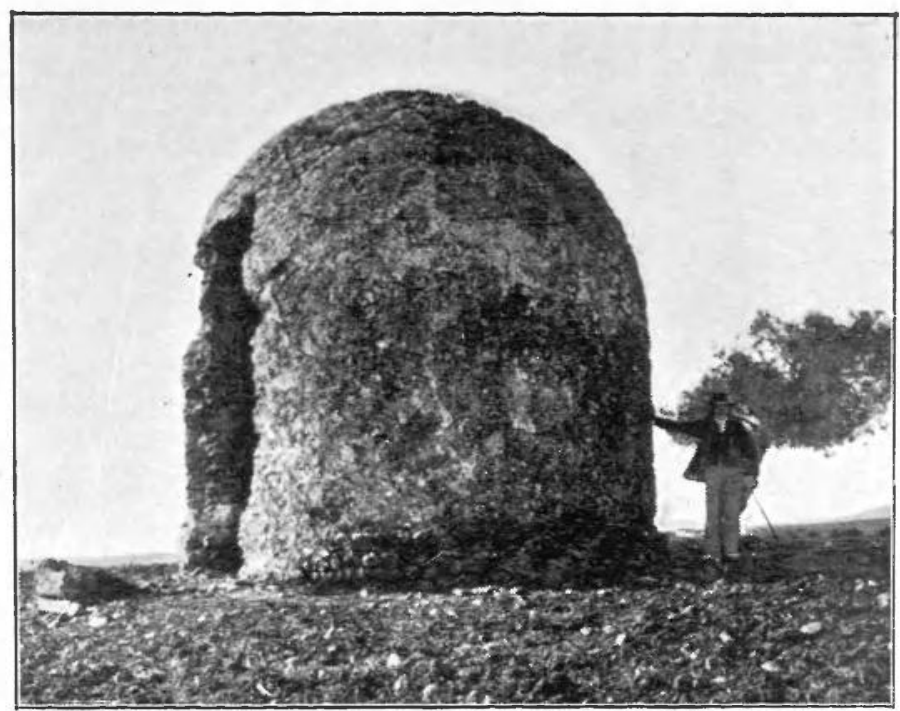

ALCOLHA. "IA BOLA,"

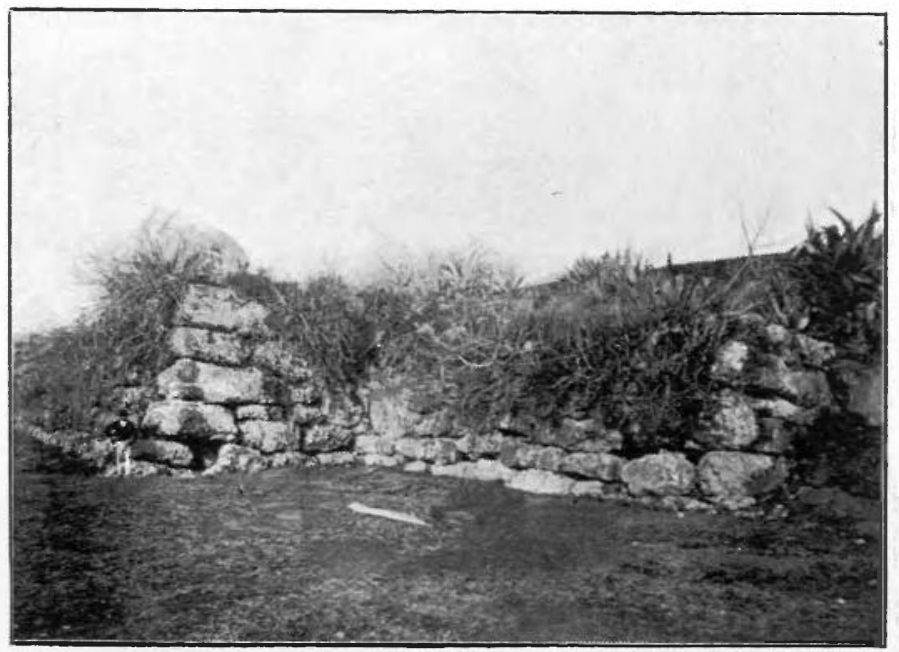

PENAFLOR. "HIGUERON." 


\section{Work at Pexaflor.}

Work was begun on this site on March 18th, and continued till April 2nd. We hađ̃ previously paid a flying visit on February 14th-15th, when we saw that there was at least plenty of evidence of Roman occupation. The town is situated, as are all the Roman towns which we investigated, with the curious exceptions of Cordoba and Seville, on a rising ground on the outside of a bend of the river. This has necessitated the construction of river defences, some portion of which yet remain, though now partially covered by deposit from the turbid stream. Below these river-walls, which are constructed of concrete, may be seen a most remarkable construction called by the natives "El Higueron," from the fact of two or three wild fig-trees having taken root in it (see photograph). $\mathrm{I}_{\mathrm{t}}$ is a construction of enormous blocks, apparently of hard limestone, measuring in some cases over 12 feet long and forming a species of bastion projecting from a wall of similar though less massive masonry. Its dimensions are about 30 feet long, 15 feet deep, and 12 high. It much resembles in character of construction the so-called Cyclopean gate at Tarragona.

Continuing to follow the river bank, we come to a very large collection of débris of a potter's workshop. Here the soil is almost literally composed of fragments of earthenware of various kinds, comparatively few specimens of the coarse yellow ware of which amphoræ were composed, and which is so common at Pena de la Sal, a good deal of Saguntine ware, both of the finer and coarser varieties, and a great quantity of a yellowish paste decorated with bands of dark red ochre, and in some cases entirely painted over with it. In all this mass of pottery we were unable to find one unbroken vessel, or even one of which the shape was still recognisable. Here we also discovered remains of what seemed to be a potter's kiln, a circular structure of concrete, but broken at the top (see plan 1).

It was here that we first broke ground, proceeding to clear out the walls, \&c., which had formed part of the potter's workshop, which also included the kiln. This work was finished March 20th. There was not much of 
interest found during the excavations; a few Roman coins of emperors, two of Claudius, and one of Seville Colonia Romula were picked up, but all in a very bad state.

On the 21st March we tried in a new direction, that is, about the probable line of the Roman road from Celti to to Detuma along the line of the river. We were guided in this by the reports which we had heard of the discovery of Roman tombs during some alterations at the house of D. Carlos Mesa in the Calle Mayor of the present town. According to the story told to us, there were some twelve sepultures found in this place, one "of stone, containing a lead coffin, a lachrymatory and some small vases," as well a "a funeral inscription." None of these various objects were now to be found, though the alterations during which they were found were still in progress. We therefore obtained permission to search an adjoining plot of ground which seemed likely to contain similar graves, and accordingly put two men on it, but various trials during three days resulted in reaching the undisturbed soil in every case without any traces of sepulture. From the character of the earth it appeared almost probable that the ground had been disturbed, if not deposited there, comparatively recently. We therefore discontinued our search.

In the meantime, we had employed our other two men in opening trenches in the olive-yard called La Pared Blanca, to the west of the present town and above it. This is separated by a road from the olive-yard of Las Moncruas, which would have been the most favourable spot probably in the whole of Penaflor; but unfortunately it was this year ploughed and sown, and by this time the young crop had grown so well that the question of compensation, which might have been considered at an earlier period, was now rather too much for us to undertake. This was unfortunate, as we saw in the house of D. Pedro Parias, Diputado, and owner of this ground, a base of a magnificent marble column of reddish (Cabra) marble, which had been found in company (apparently) with others in digging the foundations of a house. From its size it must, I think, have belonged to some public building. Another base very similar in size is to be seen in the house of D. Jose Maria Ariza, the Cura, where it serves as the bed of a potter's wheel. It is in Las 
To iace pagr 26 ?

\section{PLAN 3.}

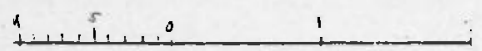

Penaflor.

Tomb of Concrete
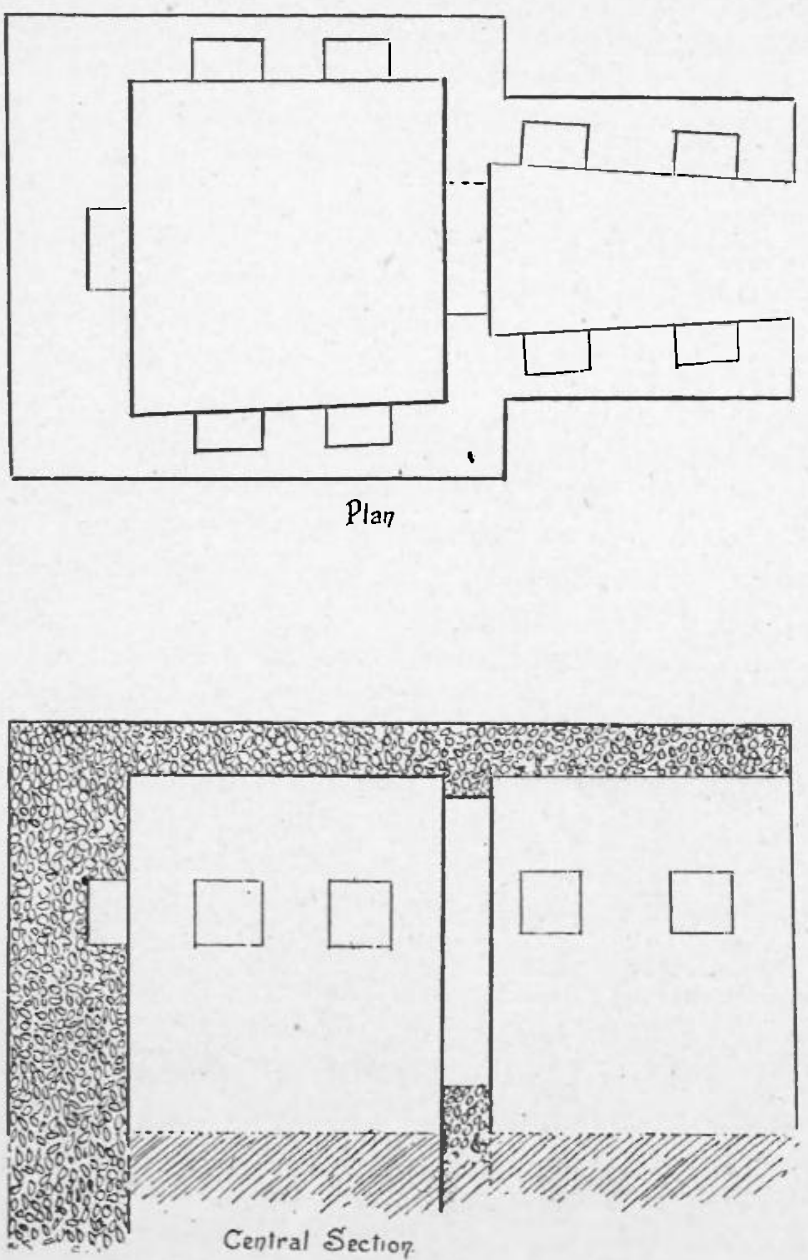
To jace paye 265 .

PLAN 2.
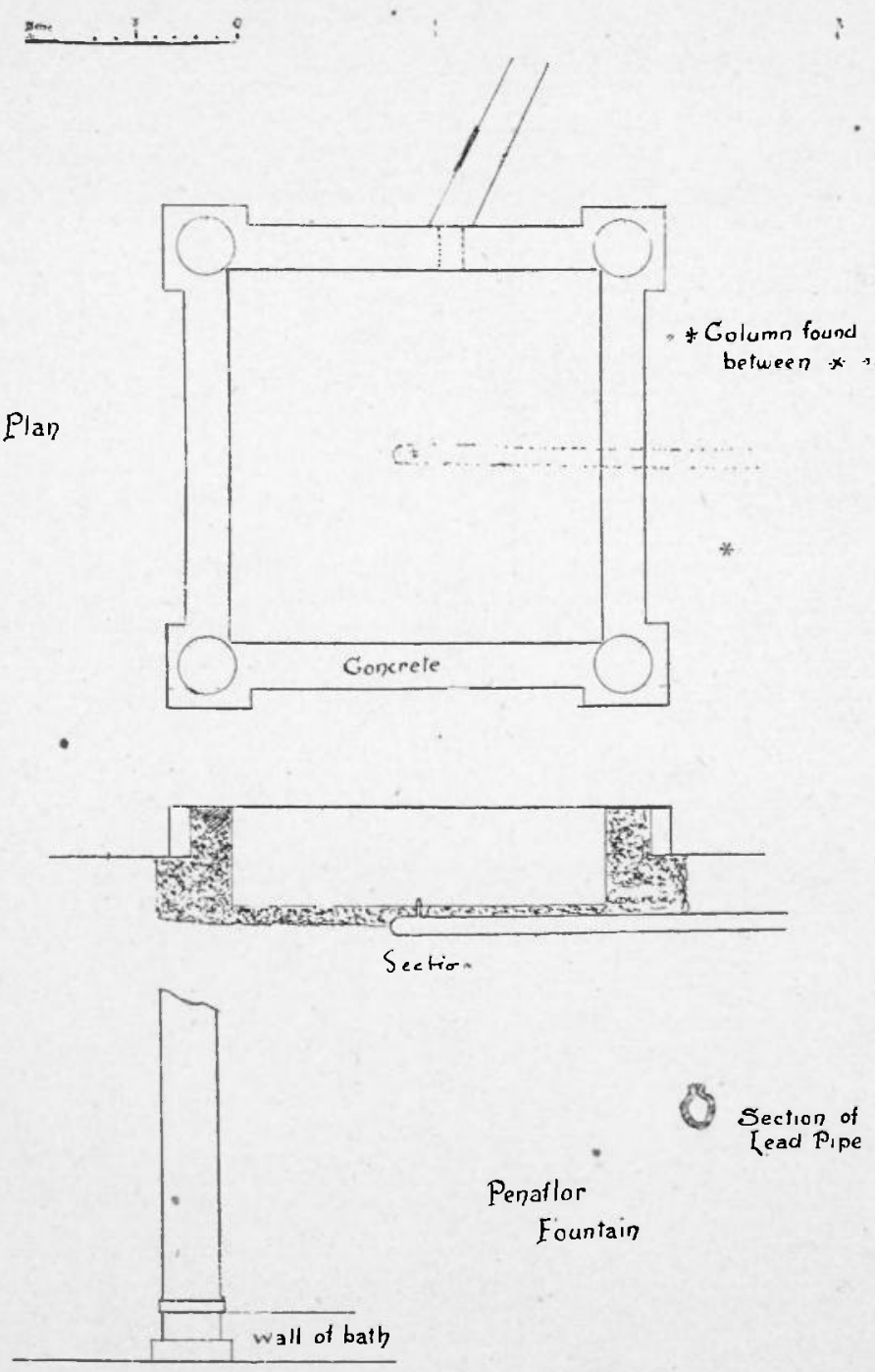
Moncruas, ioo, where it slopes to the river, that we saw a semicircular hollow in the ground, where tradition asserts that many steps were found when the railway was made. This sounds like an account of a theatre, but here again we were unable to dig.

To return to La Pared Blanca, inland from this. With the permission of $\mathrm{D}$. Antonio Cobra, the Alcalde and owner of the land, we opened various trenches, and came upon a large number of ruined walls, but the small accumulation of débris since the Roman period had not protected them much from the spade and ploughshare. We worked on this spot till April 2nd, tirst with two men, and afterwards with four. The most important discovery was that of a small square reserroir with the remains of what seemed to be a pillar at each of the external corners. In the centre was a leaden nozzle projecting from the floor and communicating with a leaden pipe, which passed under the cement floor, and presumably joined a larger pipe or main outside. We did not discover any traces of a tap or other apparatus for regulating the supply. Presumably, therefore, such an apparatus, if it existed, was on that portion of the pipe now destroyed (see plan 2).

There is also in the courtyard of the Hermita de la Encarnacion, adjoining the Moncruas, but on the town side, a row of flat stones, which we imagined might be the remains of a cleaca, since we heard much of the great distances to which it was possible to penetrate, after removing one or two of the covering stones. A practical test, however, soon dissipated these opinions ; the supposed passage is a disused burial vault about 12 feet square!

There is, however, on the outskirts of Penaflor a very interesting tomb, originally, I have no doubt, subterranean, but now partly exposed, owing to denudation. It is constructed entirely of concrete, and bears a remarkable resemblance to some of the rock-cut tombs of Carmona.

The entrance is by a narrow passage, on each side of which are two niches fur the reception of urns. The main chamber is roughly square, and contains five such niches (see plan 3). It is possible that excavation might reveal further tombs of this class. The existence 
of this specimen was unsuspected till it was discovered by accident by some men yet living in Penaflor. They do not, however, recollect anything of what was found.

\section{Neighbourhood of Penaflor.}

Peñaflor was supplied by an aqueduct which was fed by two springs called collectively Jas Fuentes de Almenara, about $5 \mathrm{kil}$. from the town in the direction of Puebla de los Infantes, and not far from the Moorish stronghold of Almenara, which commands the road between the two towns. This was presumably also the line of the Roman road through Celti to Regiana (Reyna) and Emerita. There is not, however, much sign of the more familiar type of Roman road, as the present way is nothing more than a mule track winding up the course of streams between steep-sided hills.

The two springs which supply the aqueduct are, or were, each enclosed in a well-house or other receptacle for collecting the water. A channel then led from each, joining at a short distance, and thence pursuing a single course to Penaflor. The conduit lies nearly all the way above ground, or very slightly below it, and is traceable at intervals for the whole distance, occasionally making a detour to avoid a descent and rise. The engineers who laid it down appear to have been able to avoid carrying the conduit on arches at any part of its course.

There is also near the Barranco del Portugues the remains of another aqueduct, independent of the one mentioned above. The first traces of it, so far as we were able to find them, are four or five "lumbreras" or manholes near the slope of the serro which here forms the outlying spur of the Sierra Morena. Some of these have been cleared out, doubtless in order to obtain the water, which still may be heard and seen trickling at the bottom. The aqueduct then disappears under a rise in the ground, to reappear on the other side as carried on a rough arch, now broken, across a dry watercourse. It is then again lost for a few hundred yards, to reappear at the edge of a Roman quarry, and apparently to traverse one side of it. On the farther side the specus is well to 
be seen, and is of sufficient height to admit a man. Further progress is, however, barred by the accumulation of earth, and beyond a manhole about fifteen yards farther on, the line of the aqueduct is untraceable without excavation. There are, however, a series of disused water-tanks in a field about a quarter of a mile off, and doubtless these at least were once supplied by the water which the modern Spaniard has let run to waste.

It is perhaps unnecessary to mention that after the aqueduct disappears under the first bill there is no water even when the specus is visible.

Penaflor and the neighbourhood has lately shown signs of increased activity owing to the exploitation of copper and lead mines in the immediate vicinity; and the same revival has extended to Puebla de los Infantes, which we visited on March 22nd. We imagined that we might find considerable traces of Poman occupation, as it has occasionally been identified with Celti. We found, however, no such traces in the town; there is a despoblado called Margolla in the vicinity, but no town.

Plin. Hist. Naturatis, III, 3, 10.

". . dextra Corduba colonia Patricia cognomine, inde primum navigabili Bæte, oppida Carbula, Decuma, fluvius Singilis, eodem Brtis latere incidens. Oppida Hispalensis conventus Celti, Axati, Arva, Canama, Evia, Ilipa cognomine Ilpa, Italica, et a lævo Hispal Colonia cognomine Romulensis, . . ." \&c.

\section{Translation.}

"On the right bank is the colony Corduba surnamed Patricia; below this the Bætis is first navigable, the towns of Carbula, Decuma, and the river Singilis falling into the Bætis on the same side. The towns of the conventus of Hispalis are: Celti, Axati, Arva, Canama, Evia, Ilipa surnamed Ilpa, Italica; and on the left bank the colony Hispal, surnamed Romulensis."

Strabo. Bk. III, c. 2, §3. (c. 142.) Ed. Kramer, 1844.

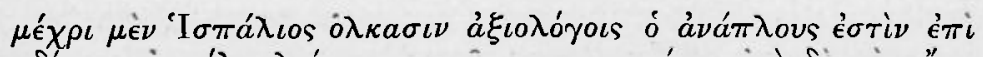

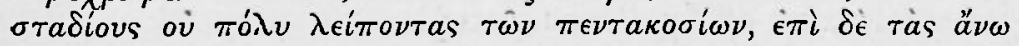




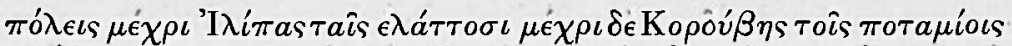

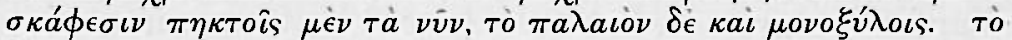

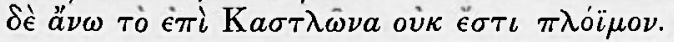

\section{Translation.}

"As far, then, as Hispalis, merchantmen of considerable size can sail, a distance little short of five hundred stadia, while to the upper towns as far as Ilipa lesser ships can ply and river-boats as far as Corduba. These are now built, but were formerly also 'dug out' of one tree. The apper reaches towards Castulo are not navigable."

\section{Id. c. $5, \S 8$. (c. 174.)}

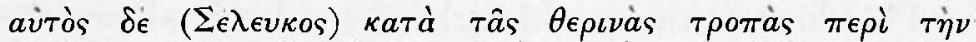

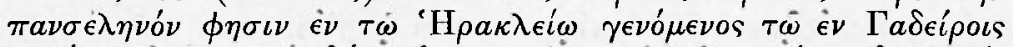

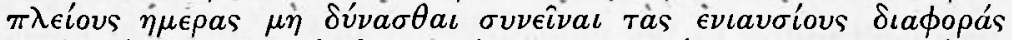

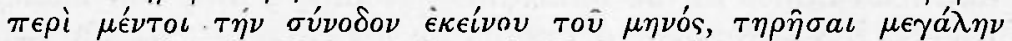

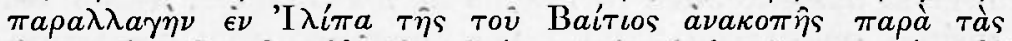

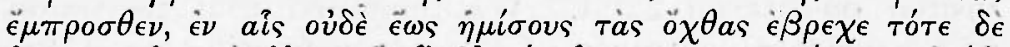

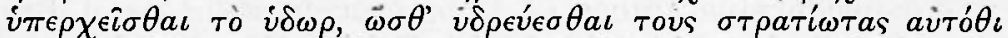

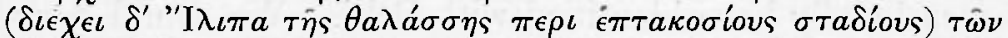

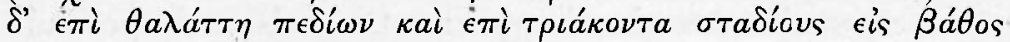

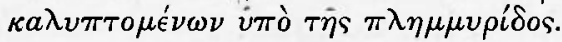

\section{Translation.}

"He (Seleucus) says that when he once happened to be, at the summer solstice, about the full moon, in the Heracleum at Gades for several days, he could not hit upon.the annual differences; but that ahout the end of that month he noticed a great change at Ilipa in the holding up (by the tide) of the Brtis from former occasions, on which not half the bank was covered; whereas then the water rose so high that the soldiers drew water in the town itself. Now Ilipa is about seven hundred stadia from the sea. And the plains towards the sea were covered for a distance of thirty stadia, to a. considerable depth."

\section{The River from Peñafor to Peña de la Sal.}

\section{Right bark, from Peñaflor to Lora del Rio.}

February 14th. About 2 kil. below the town is a despoblado, not of any great extent, but chiefly remarkable for a defending wall against the current, constructed partly of potsherds, as is the common custom, with rows of bricks at intervals, and partly of rows of amphoranecks, the mouths of which form a series of holes in the wall. It is this peculiarity of appearance which has led to. its local name of La Botica (see plan 4). 
Wall of large Silones and Potsherds Peña de la Sial.
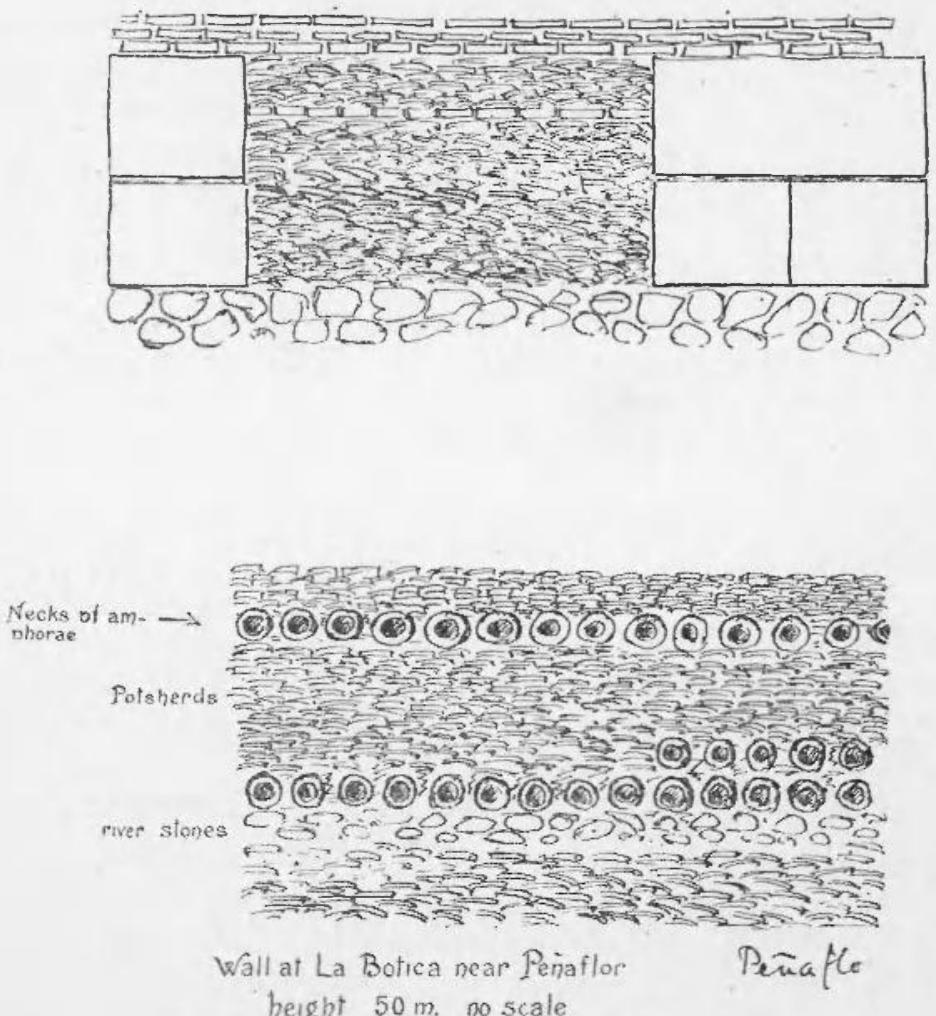
A short distance lower down, and at about 1 kil. from the river, is the tower and church of Villa-Diego, where there are considerable indications of Roman settlement. The spring, an almost unfailing indication of a Roman site, appears to flow from an ancient Roman channel, but as it is situated at the bottom of a dark hole, investigation is naturally somewhat difficult. In the corral of the church is to be seen a handsome Corinthian capital of white inarble.

March 24th. The next despoblado to be met with is that of La Tablada, on the arroyo of that name; here there is a considerable extent of tierra de villar and the remains of several cisterns. In one of these the extant part is semicircular in plan, $5.95 \mathrm{~m}$. internal diameter, $\cdot 55$ thickness of wall (concrete); but whether the circle was originally complete cannot now be determined. In another case the cistern is rectangular, $3.02 \mathrm{~m}$. in width by at least $3 \mathrm{~m}$. in leugth, the further end being broken, depth $1.45 \mathrm{~m}$., thickness of wall $\cdot 45$. Another has failen almost entirely into the river below, which at this point has eaten away much of the bank. The spring, which once doubtless supplied these cisterns, now breaks out in the face of the river bank at a much lower level, owing, perhaps, to the stoppage and destruction of the ancient Roman aqueduct. Remains of such an aqueduct are to be seen about $300 \mathrm{~m}$. lower down the stream, near the arroyo Los Gatos, consisting of Roman hewn stones of the usual dimensions, $1 \cdot 20$ by $\cdot 60$ by $\cdot 60$, with a rectangular channel of perhaps half these measurements cut in them, and then possibly closed with a thinner slab of stone at the top, thus. There is also sufficient tierra de villar to distinguish this as a separate settlement.

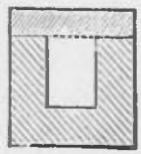

From Tablada, according to D. Antonio Parias, came an inscription which we saw in his house, but from its size, which appears to indicate the architrave of a temple or public building, and the apparent mention of a Sevir Augustalis, this seems unlikely, and it is more probable that it came, originally at least, from his olive-yard "Las Moncruas," of which we have spoken above in treating of Peñaflor (p. 262).

The next despoblado is to be found on the arroyo of 
El Berro, but there is not much to be seen except tierra de villar; but at a short distance down the river we come 10 the farm of La Maria or Aldelamaria, which is one of the sites mentioned by Guseme in 1758 in the $\mathrm{Mem}$. Acad. Sevill, 1773, as a Roman station. He speaks there of "numerous remains," "the spring," which yet exists and is very strong, and " concrete, which appears to be the base of a tower," doubtless a square cistern, which, however, is not now to be seen. He also gives the following inscription as extant there :-

$$
\begin{aligned}
& \mathrm{IVNIVS} \cdot \mathrm{I} \cdot \mathrm{S} \cdot \mathrm{S} \cdot[\mathrm{T} \cdot \mathrm{T} \cdot \mathrm{I} \quad \text { (C.I. L., II, 1069). } \\
& \mathrm{P} \cdot \mathrm{I}
\end{aligned}
$$

This inscription we were unable to find. (Cean Bermudez, in copying this description, here places "Nema Turdetanorum," for what reason was doubtless best known to himself.) There are also on the river bank considerable remains of walls of potsherds.

Following now the ancient bed of the river, to the north of the present, we come to the hut of La Maiena, where there is much tierra de villar. The following marks were found, but as yet are unintelligible, all badly formed:-

$$
\begin{aligned}
& \text { AV :HR ? (140) RAAN? (141) } \\
& \text { AVIH ? (142) }
\end{aligned}
$$

A little farther on, where the arroyo Matache joins the river, there is an unimportant despoblado, containing nothing but tierra de villar, to which we have given the above name.

We now cross the Guadalvacar and the arroyos Salto de la Mata and Helecho, close to which there is a fountain, probably of Roman origin. Close by, on the old bank of the river, now $300 \mathrm{~m}$. from the present, is Las Huertas del Rio, a despoblado of considerable extension, and containing large accumulations of potter's refuse. Here we found the following stamps on amphora handles :-

IIIENN $\cdot$ IV (135)
SENANS (138)
IIIMMI $\cdot$ RIV (139)

PECS无N (136)

- AENI (137)

135 occurs also in C.I. L., II, 4968, 27, doubtless from the same spot, and also in Rome. As we found five examples in about a quarter of an hour, and Hübner 
gives another, it is possible that this was the place of their manufacture.

March 9th. Though it does not by any means lie on the river, but at a distance of 5 kil. to the north, it may not be out of place here to give an account of the famous sanctuary of Setefilla, which has been considered a Roman site, as well as one occupied during the middle ages. It is best approached from Lora. A short distance before reaching the Convent we pass a Roman aqueduct in a ruined state, which, however, crosses the road and does not follow it. We then see some tumuli grouped together on the upper side of the road, and then, having gradually been rising all the way from Lora, we descend into the steep ravine of the Guadalvacar, and rise again, perhaps even more steeply, to the isolated rock of Setefilla. A few moments assured us that we had here no Roman site, at least of the ordinary kind; there was no concrete, no tierra de villar, such as we were accustomed to, but on the other hand a castle built with tapia walls, and a hewn stone tower of the 13 th or 14 th centuries.

Cisterns there were, but of Moorish type, underground, with barrel vaults, and lined with characteristic reddish cement. The inscription C.I.L., 1071, which is the only one reported from this place, we found at last in a stable under more than a foot of manure. It is correctly given. It at present serves as part of the foundation of the stable, and has been there beyond the recollection of the inhabitants. There is, however, no reason why it should have been originally set up there, especially since at a short distance, close to the farm of El Membrillo, we find an extensive Roman despoblado, which was once the establishment which grew up round the sulphur-spring, which is still in great repute in the neighbourhood. Is it not possible that the LACVS - ET - AERAMENTA mentioned in C.I.L., II, 1071 as erected by Sergia Salvia in accordance with the will of Saturninus Rufus, her late master, may be tanks for containing this same medicinal water, and the copper fittings thereof? There have been a great number of coins found here, many perhaps votive offerings to the goddess of health, but we did not see any of them. 
We saw in the courtyard of the farm the following fragmentary inscription :-

\section{DIVO $\cdot A V G V S:$}

in letters about $6 \mathrm{~cm}$. high, apparently of the age of Tiberius (unpublished).

About 1 kil. from this, in the direction of the river, is a large tank $11.00 \mathrm{~m}$. by $5 \cdot 50$, and still containing water, which is exceptional among Roman cisterns. There are also traces of the aqueduct which apparently supplied the water. A small quantity still trickles along it,

II. Left Bank. Penaflor to Lora del Rio.

March 24th. The first despoblado which we come acruss is at the arroyo of Sotogordo, which contains a good deal of tierra de villar, and what appears to be a well-a circular stracture of $.73 \mathrm{~m}$. internal diameter, $.45 \mathrm{~m}$. thickness of wall, depth unascertainable, as it was choked up at a few feet from the surface. It was built, not of concrete, but aiternate layers of water-worn stones and bricks set in mortar.

There is now a large space unoccupied by Roman remains. We cross the river Madre de Fuentes, climb the lofty Barranco de los Ciegos, and descend to the stream of Matillas. After this we come to the farm of La, Rambla del Palo Dulce. Here there is a despoblado, containing a cistern with circular mouth of 90 aperture, expanding somewhat below, thickness of wall 52 . From the shape this might at first appear Moorish, but the concrete is completely Roman in appearance, as well as the lining cement, which differs completely from the reddish cement usually employed by the Moors. There is also here a great reservoir $32 \cdot 20 \mathrm{~m}$. by $19.75 \mathrm{~m}$. The walls remain to about 80 in height, are .51 in thickness at one end, and .62 elsewhere, there being a set-off at that end, and are supported by buttresses at the corners.

March 10th. At La Rambla, strictly so-called lower down the river, there appears to have been found a leaden coffin "with inscription" some years ago (it was impossible to ascertain the date). It seems to have been sold. 
At El Acebuchal, farther down, we noticed tierra de rillar, and picked up an imperfect amphora handle :-

$$
\mathrm{L} \cdot \mathrm{r} \cdot \mathrm{L} \cdot \cdot \cdot(144) \text {. }
$$

At La Catedra we passed over a large extent of tierra de villar, without discovering anything of importance.

This brings us close opposite Lora, but it will be best to diverge somewhat to the south and describe Lora la Vieja, an important despoblado 5 kil. south-east of Lora. It is mentioned by Guseme with La Maria ( $v$. supra) as well as Los Gallos, Setefilla, \&c., of which afterwards. It is situated on the crest of a low hill which bounds the valley proper of the Guadalquivir, and no doubt was a strong position on the road from Axati to Astigi, which passed here. Guseme mentions a pool at the top; this doubtless, again, was a reservoir, but has now disappeared among the numerous formless concrete fragments which strew the ground. Here among the bricks, potsherds, \&c., which abound, we obtained the following marks :-

L.V.TRoPIM (113) (Cf. C. I. L., XII, 5683, 305) and ORFS (114).

Returning towards Lora, we have 3 kil. to the west the farm of Los Gallos, where one can see now, as Giseme did in 1758, much tierra de villar, Roman hewn stones, \& c., and a spring.

El Puerto is half-way between Gallos and Lora. Here there are also remains, but of no great importance, and here was found the inscription published $C$. I. L., II, 1058,9 .

\section{Axatr.}

The next town given in Pliny's list is Axati.

From an inscription given by Huibner (C.I. L., 1055), said to be extant in the parish church of Lora, but which now seems to have disappeared, we may conclude that Axati stood on or near the ground occupied by the modern Lora del Rio, and this has been the opinion of all writers who have occupied themselves with the subject. There are other inscriptions found in Lora, which indicate that there was there a town of some 
little importance $(1054,1057)$, but these unfortunately do not give us the name of the town to which they belonged.

In the modern town we find the usual indications of the proximity of a Roman site-squared stones, fragments of columns, capitals, \&c. The height occupied by the ruins of the mediæval castle of the Knights of St. John is just such a height as the Romans sought, on which to plant their cities. ${ }^{1}$ The soil, however, though containing a good deal of broken pottery, is not so full of it as either at Peñaflor or Peña de la Sal, of which we shall treat presently.

III. Right Bank. Lora del Rio to Peña de la Sal.

January 25 th. In this comparatively short stretch of river, we have no Roman despoblados on the actual bank, but there is on the line of the present (1889) road, and doubtless on that of the Roman, a huerta called La Fuente de la Mora, about half-way between the tro towns. There is here the usual spring, in this case retaining part of the Roman channel, much tierra de villar, and other debris. About twenty years ago there were some sepultures found, with fragments of funeral inscriptions, which have now disappeared.

Between this site and the river there is a small despoblado with remains of a reservoir, to which we give the name of Villar for want of another.

Between Fuente de la Mora and Peña de la Sal, at the passage of the stream Algarin, there may be seen some large Roman stones, and a few metres farther the remains of a small reservoir.

IV. Left Bank, from Lora to Pena de la Sal.

February 13th. The first Roman site is at the farm of El Indio. The bank here is much undermined by the current, and many fragments of concrete and stone are lying in the river. There also appears to be, half buried in the bank, a Roman kiln, which is now half destroyed, and the rest buried.

January 25th. At Azanaque, a short distance farther down the stream, and at the mouth of the small river of that name, is a Roman despoblado, though, as might

1 There does not appear to be anything older than Moorish tapia in the walls of the Castle. 
be guessed from the Moorish-sounding name, the remains of the Roman occupation have been almost hidden under later constructions of tapia and weak concrete. Still, there remains sufficient to enable us to class it under the head of Roman despoblados, though not among the most important.

On an old bank of the stream, about $\frac{1}{2}$ kil. from its present course, is to be seen a small and unimportant despoblado, to which we have given the name of the adjacent farm of Los Giles.

We are now opposite Peña de la Sal.

\section{Arva.}

Arva is placed by Hübner at Aicolea de Rio, following in this the lead of erroneous information ${ }^{1}$ and apparently unaware that as early as the end of the last century, Thomas Guseme, a judge at Lora, had published in the memoirs of the Seville Academy a paper, in which he assigned to Arva its true situation at Pena de la Sal, about three miles above Alcolea. From this spot come all the inscriptions which mention the name of Arva, with one exception (C.I. L. 1060), which is stated as being in Alcolea by Caro, and here there are very extensive remains of building, such as arches of concrete, baths, river wall, \&c. The ground is full of fragments of amphoræ, marble slabs, \&c., and other evidences of a considerable Roman town. Here, too, has been found the hitherto unique coin of Arva, if coin it can be called, discovered in 1885-of lead, blank on one side, and having the figure of a horse with the letters M.F.A. on the other. A large number of the amphora handles. discovered here last winter had $\mathrm{AR}$ as their final element (e.g., No. 53).

The identification of Arva with the Pena de la Sal may thus be considered certain.

\section{Pẽ̃a de LA SAL.}

Work on this site was begun on December 12th, but owing to various difficulties with the owner of the greater

1 E.g., 1064, where Hübner does not realise the distance between Alcolea and the Peũa de la Sal. 
part of the ground operations had to be postponed, and were not resumed till January $22 \mathrm{nd}$, when we set to work in earnest. The site consists of an irregular elevation on the right bank of the Guadalquivir, and bounded by two small streams, the Arroyo de la Mezquita, and another which is usually dry. On the farther (eastern) side of the first-named may be traced at intervals the channel of the aqueduct which supplied the former town, and down which the water of the present arroyo must in great part have run.

The extent of the town is fairly clearly marked by the potsherds, which begin almost suddenly after crossing the arroyos, on the bottom of the valley which bounds the site on the north, and cover the whole area thickly. The greater part of these potsherds are fragments of amphoræ, and include those which are entered under the head of "Peña de la Śal" in our list of potters' marks. There also occur large quantities of the so-called "Samian," Arretine, or Saguntine ware, both of the finer and coarser varieties; but comparatively little with reliefs, and very few potters' stamps.

The ancient city appears to have consisted of (1) the higher or northern portion, which may be considered as the citadel, and which in the last century was surrounded by at least the remains of a wall, with towers at regular intervals; and (2) the lower portion between this and the river, which also appears to have been inhabited by the poorer part of the inhabitants. This lower city was defended from the encroachments of the river by a concrete wall, which is still clearly traceable for some hundred yards, though now at a little distance from the water, owing to a retreat of the river-bed. There is also just inside the wall a bath of a most remarkable shape. In the upper part of the city are the following remains of building above ground :-

(a) A square erection, with another adjoining it, of a semicircular shape, which turned out, on investigation, to be a bath, so far as we were able to judge.

(b) A mass of concrete in the form of a rough arch, whether original or thus shaped by excavators 


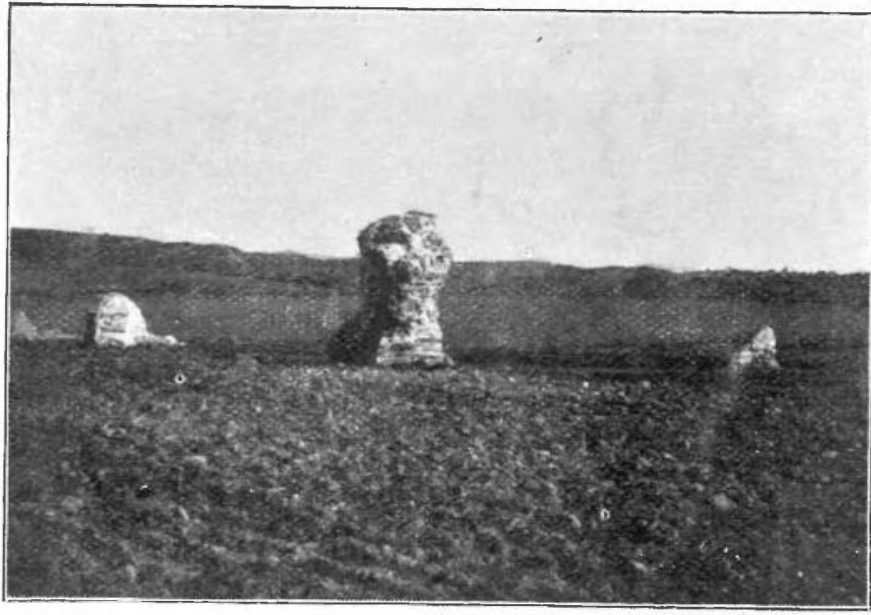

"LAS TORRECMLAS."

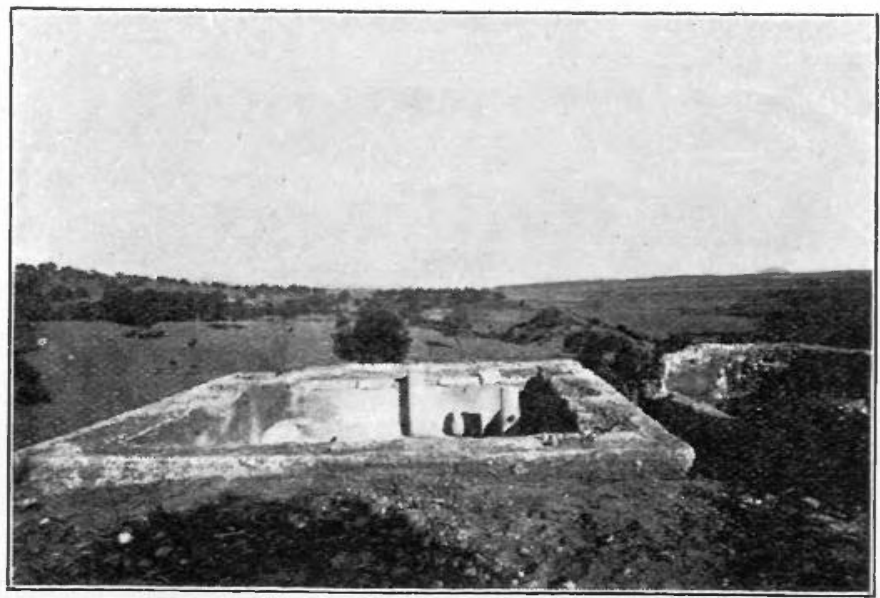

PENA DE LA SAL. LARQE BATH. 
In face page $2: 4$.

PLAN 5.

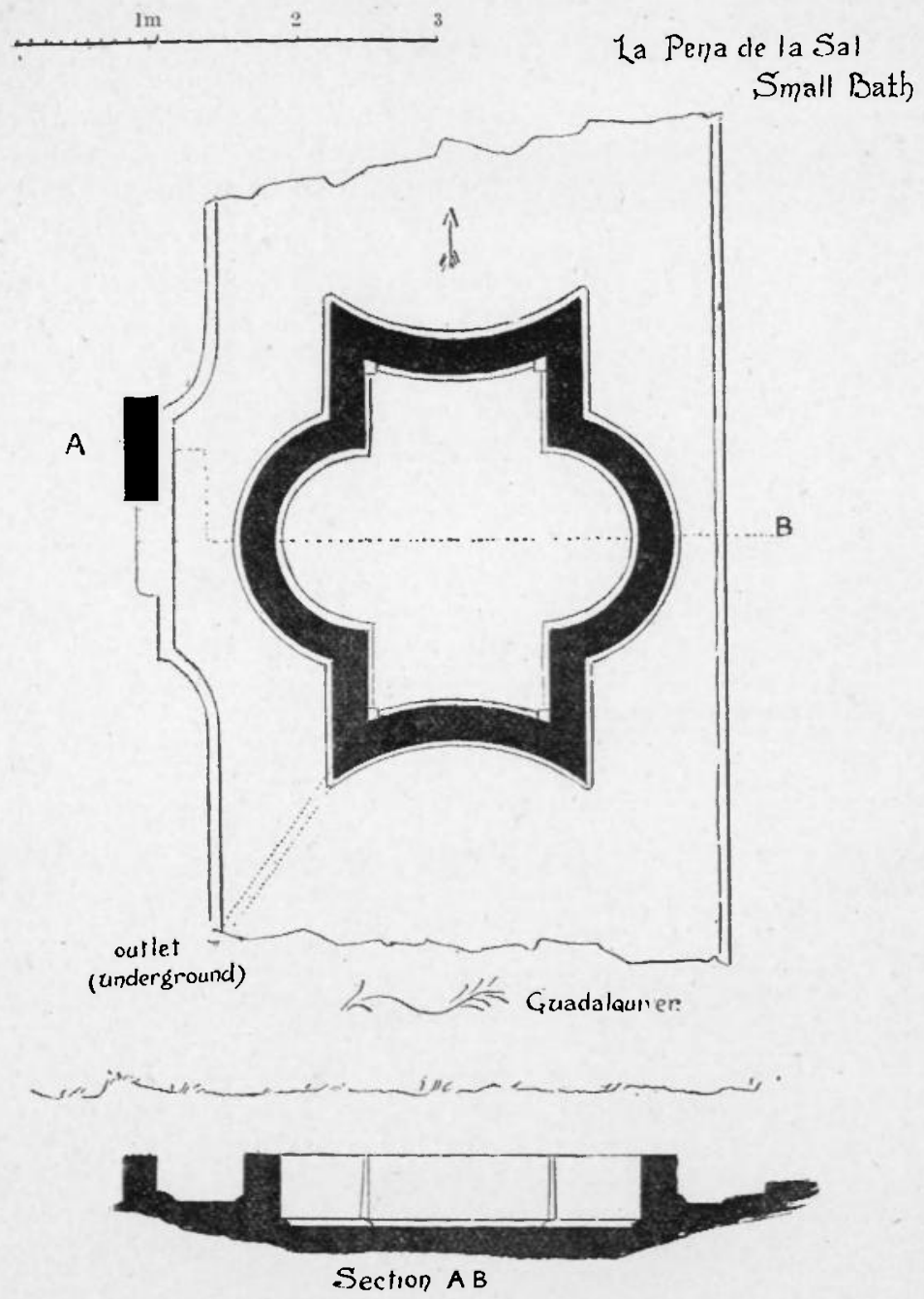


PLAN 6.
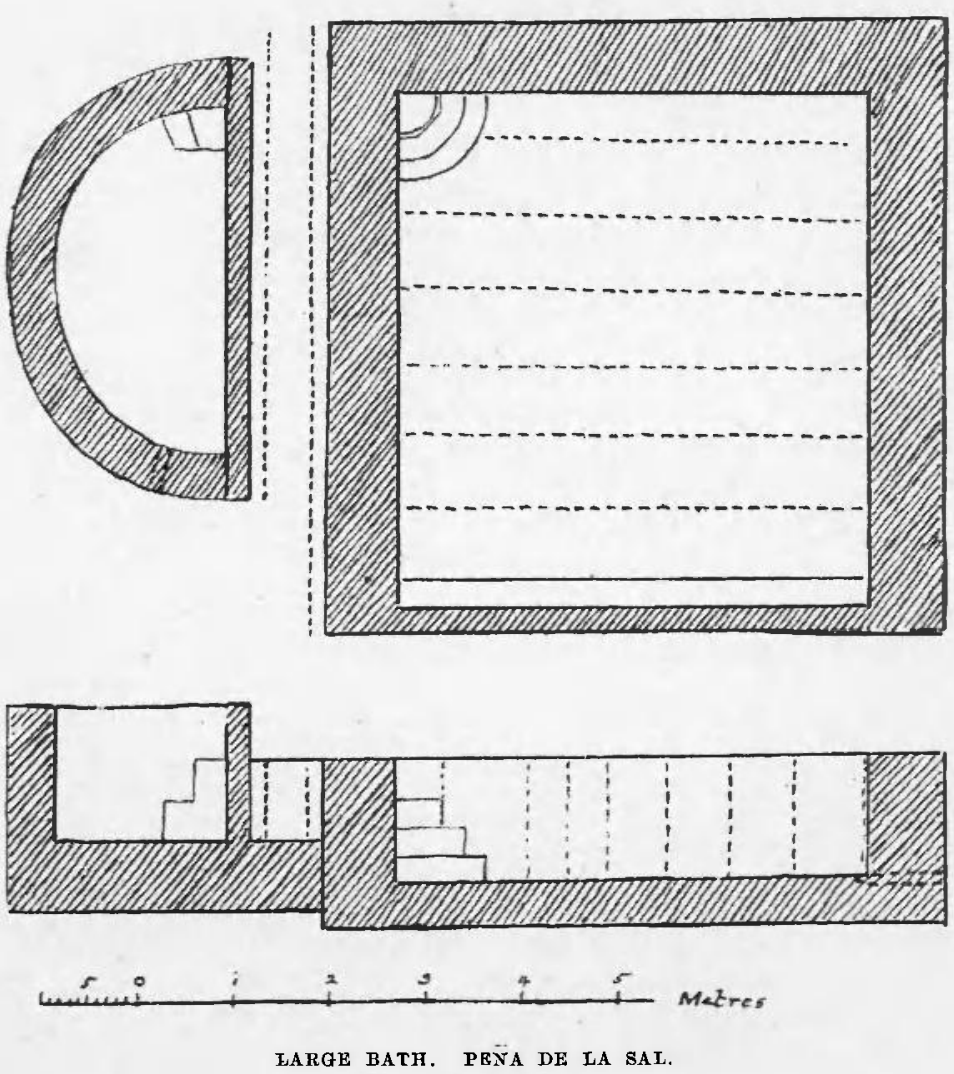

Plan and Section. 
admits of some doubt. Its original use and form we were unable to decide.

(c) Some ill-defined concrete constructions on the side of the hill towards the river, which appear to have been the substructures of some large building which has now disappeared. Though now choked with stones and undergrowth, to an extent which makes the introduction of a human body a matter of considerable difficulty, they have the appearance inside of having been cast round arched centering.

We selected for our first trials the large square bath, of which but little was to be seen beyond the outline of two sides. This was begun on January $22 \mathrm{nd}$, and finished on the 30th. Its general plan and appearance when clear may be gathered from the plans and photograph. It seems to have consisted of a square tank lined at bottom and sides with thin marble slabs, with three steps each of a quarter-circle in plan at one corner. It seems to have had an open colonnade round at least three sides; what the arrangement of the fourth was we have not been able to determine. The columns were monoliths of a species of marble common in this district-greenish grey with purplish veins. Several fragments of these columns were found lying in confusion at the bottom of the bath, but though we were enabled to piece in one instance three fragments together, we were unable to recover a complete specimen, which must have been about $\delta$ feet long. That the capitals of these columns were Corinthian is rendered probable by the discovery of the extreme corner of such a capital in the earth which was removed. The fragment is not above 2 inches long, but is clear evidence of the form which the capital had when perfect. Of the entablature we can unfortunately form no idea.

Adjoining this bath and between it and the apsidal portion there is a passage, which perhaps served as a conduit for the water which supplied the baths. For that the apsidal portion too was a bath is proved by the prints of the marble lining-slabs on the flcor, and by the hules which held the iron and bronze clamps (in some cases still remaining, though broken) to secure similar 
slabs to the walls. I have called this passage a water conduit, since there appears to come from it an opening into at any rate the square bath, at a higher level than the floor. It was originally brick-lined; what the covering, if any, was is now only a matter of conjecture.

Beyond the apsidal portion there are traces of brickfaced concrete walls, but no certain information is to be derived from them. And here attention may be drawn to a distinction which exists between these (and all other brick-faced walls which we found in Spain) and the similar walls which abound in Rome. The Roman examples are faced with triangular tiles with their points inward; the Spanish walls with rectangular tiles laid stretcher-wise.

We are thus left in a state of almost complete ignorance regarding the appearance when perfect of the structure of which these tanks formed a part. We are not in much better case with regard to the lower bath, mentioned above as just inside the line of the river-wall. Of this also we give plans and a photograph.

The material of which the core is built is concrete, but of a softer kind than that employed in the upper bath, and easily damaged by an incautious stroke of the pickaxe. The shape of the bath will be readily understood from the plan, more so than from any description. This has also been lined with slabs of marble, as is proved from the prints yet to be found in the cement at the bottom, and from small fragments of the slabs themselves remaining here and there in the corners. A noticeable feature of this bath is that both the outer or shallower and the inner or deeper portion were intended to hold water, since we find in each that peculiar roll in the corners and joints which was used by the Romans when intending that any construction should be water-tight. (See a good example of this in Wright, The Celt, the Roman, and the Saxon, p. 168-9, ed. 1853.) This bath was excavated by ourselves simultaneously with that described before.

On the 28th of January the site was invaded by an army of workmen engaged on the construction of a new carretera or high road fiom Lora to Alcolea and Villanueva. To obtain a level road, they cut a trench some 25 feet wide and of varying depth, up to 9 feet in some 

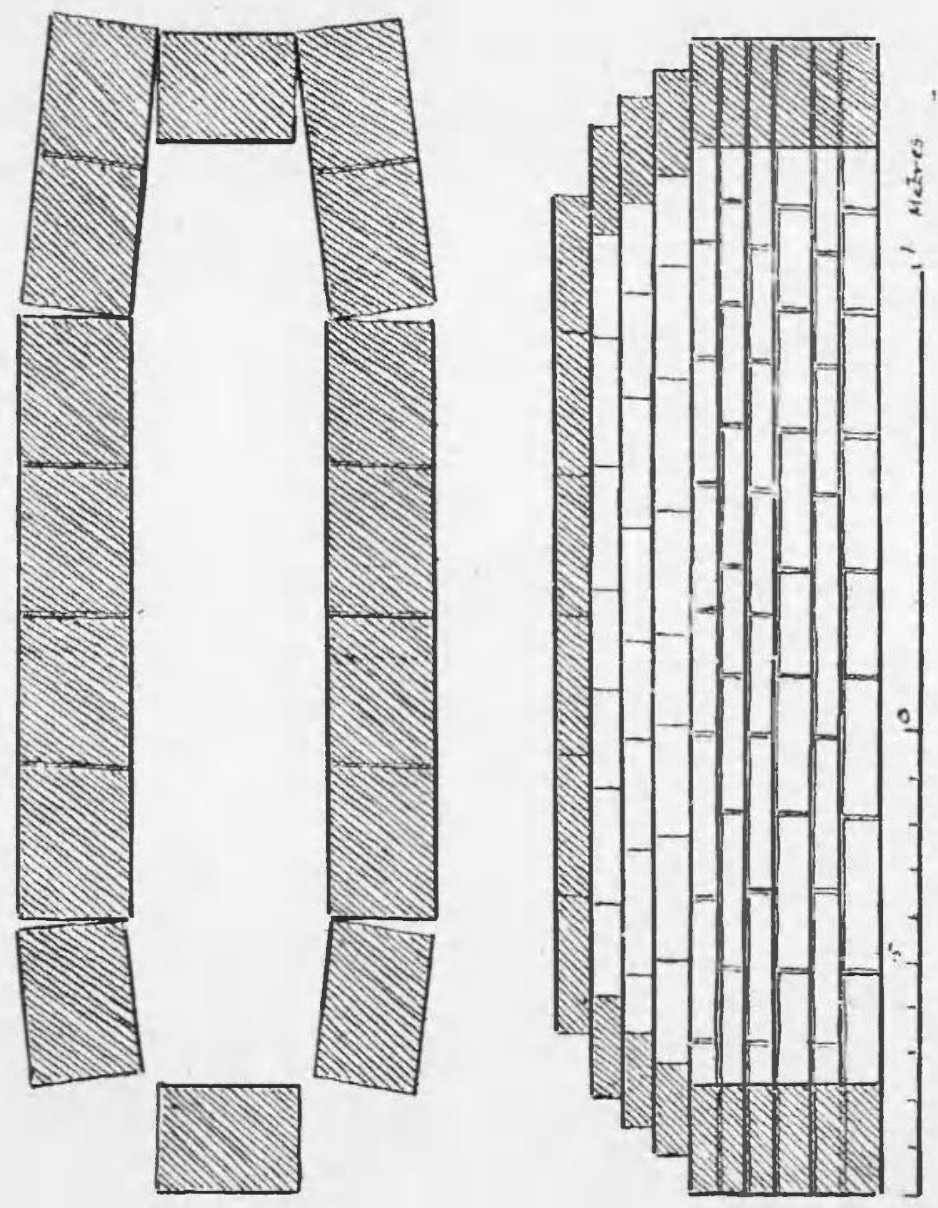

PEX̃A de LA sAL. (Tomb No. 1.) 
parts, through the whole length of the site from end to end. We therefore not unnaturally concluded that such an excavation could hardly fail to bring to light some objects of interest. Nor were we disappointed. On the second morning of their work, we heard that they had found a tomb. On investigation we found it to be a grave built of brick and covered by overlapping layers of the same. Similar tombs appear to have been found in England (see Wright, op. cit., p. 312, for mention of apparently such a tomb in Bartlow, in Essex), but whereas in the English example the tomb was under a tumulus, lay north and south, and contained burnt bones in a glass urn of a type uncommon in Spain, in those at Pena de la Sal there was no such tumulus, the body lay east and west and was buried unburnt. (See plan anc Section 7.) The most careful search of the small layer of earth which covered the bottom failed to discover a single object which had been buried with the corpse. The bricks of which the grave was composed were of two classes(1) those which formed the sides, plain bricks $29 \times 23$ $\times 6 \mathrm{~cm}$. and $(\dot{z})$ others formed thus :-

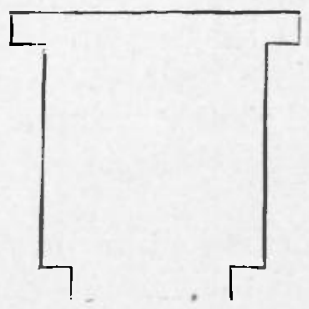

On the following day (January 29th), the workmen came upon two more sepultures of the same kind, and precisely similar. From the third we succeeded in extracting the skull, which was in good preservation, but did not find a single object. On the 31 st five new graves were discovered, three of them of small size and apparently of children, otherwise of exactly the same construction as those previously discovered, one of full size. The remaining sepulture was similar to a class of grave discovered in the necropolis at Carmona, being 
formed of six large tegulæ or roofing tiles, three on each side inclined to one another, and covered at the ridge with smaller pieces, while the ends are closed by two more tiles. Underneath these the body was laid, apparently without a coffin. Such an arrangement was, naturally, not so efficient a protection for the body as the rraves previously discovered and described, and accordingly, in this and all other subsequent interments of the same nature, the grave chamber was found full of earth, and the bones completely decayed. Similar graves to these, and their parallels at Carmona, have been discovered at York, one of which, discovered in the year 1833 , is preserved as it was found in the museum of that city. The only difference in construction observable between the Spanish and English examples is that the York grave is covered at the ridge by four ridge tiles, and has each side composed of four instead of three tiles. tnother example from the same neighbourhood was composed of three tiles on each side, but differed from those at Pena de la Sal in covering several urns, standing on a flat-tiled pavement. This class of sepulture has not, I believe, been found in England elsewhere than at York, and it is a noticeable fact that each of the tiles which composed these bore the stamp LEG $\cdot$ IX $\cdot$ HISP, ${ }^{1}$ thus pointing to a possible Spanish origin of the practice (Wright, p. 304, and plate). Similar graves to this have also been discovered at Strasbourg, belonging to the eighth legion.

On the 1st of February three or four new tombs were found, and by the 2nd their number was increased to 21 ; 17 being of brick, of which four were small, apparently of children, and four of tiles. Not one of these contained a single object, nor did any of those subsequently discovered, which brought the number up to 32 . All the brick graves were similar, not varying more than an inch or two in length, breadth, or height. But one (21) had an addition to the ordinary type, by being roofed at the top of the sides by four tegulæ laid across, above which were the overlapping courses of brick, as usual.

Another, discovered on February 1st, was roofed with

1 This inscription dates the grave between 71 or 72 and c. 123 (English Hist Review, Tol. 2, p. 645-651). 
Tombs at Peña de la Sal.

(Measurements in Metres.)

*1. Bricks $1.92 \times 40 \times 40$ deep.

2.,$\quad 1.75 \times 45$ (W.) to 43 (E.) $\ldots \quad$ bottom of 3 tiles.

3. $\quad, \quad 1.77 \times 49 \quad \ldots \quad \ldots \quad \ldots$ skeleton in good

4. $\quad 1.22 \times 134$ to $\cdot 30$ preservation.

5. $\quad " \quad 2.3 \times \cdot 54$ to 43 .

a child's.

6. " $\quad .87 \times 35$

a child's.

7.

8. " $\quad 1.16 \times 34$.

9.,

10.

11. $" ~ 2.00 \times 60$ to $54 \quad \ldots \quad \ldots$ bottom of bricks.

12. $" \quad 77 \times \cdot 30$ to $28 \quad \ldots \quad \ldots$ child's, bottom of

13.

14. Tiles tiles.

child's.

15.

16. Brick.

17.

18.

19.

20. Tiles.

*21. Brick of 4 tiles.

22. "

23. "

24.

25.

26

27. Tiles

28. Bricks

29. , $1.87 \times 47$

$30 . \quad, \quad 1.72 \times \cdot 46$ to $\cdot 44$

31. $\quad, \quad \ldots \quad \ldots \quad \ldots$

32.,$\quad 88 \times 25$ to 20 .

double roof, tiles and bricks.

child's.

* See separate plans to larger scale.

PLAN 9.

0.005 to the in.

\section{River runs so $\ggg$}

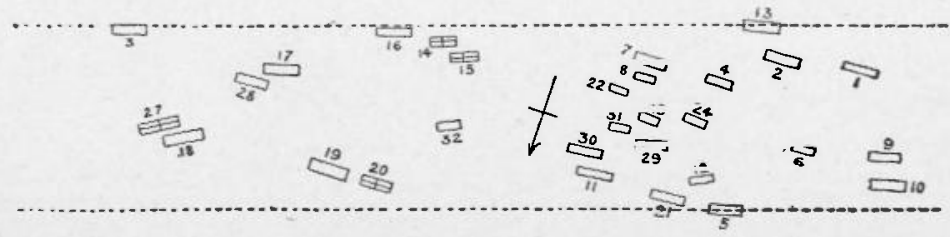

ROUGH KEY-PLAN OF THE POSITIONS OF THE SEPULOHRE AT PENA DE LA SAL. 
PLAN 8.
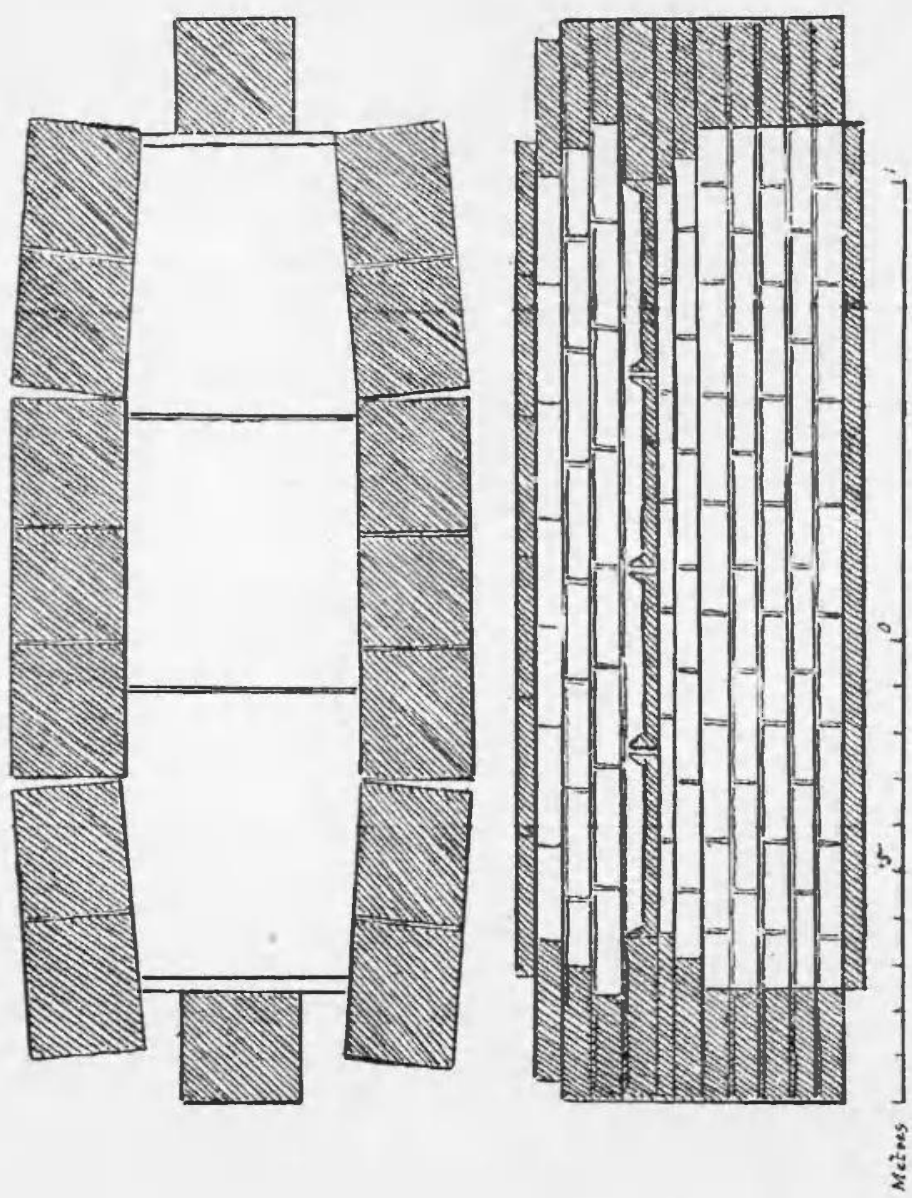

PENA DE IA SAL. (Tomb No. 21.) 
a large stone slab insteal of the usual bricks, but this probably is due rather to accident than design.

Taking into consideration the following : (1) the complete lack of objects in these graves; (2) their position in every case east and west, and in every case where evidence was certain with the head to the west; (3) their place, in the lower part of the old Roman town-it seems on the whole probable that they are of late date, and rery possibly Christian in character, if not actually of Christians.

On the 5th of February we removed our workmen from the vicinity of the carretera, where they had been working since the completion of the large bath, and set them to try the ground on the high ground to the north beyond the arch. After some time we came across traces of painted plaster, and eventually succeeded in exposing about $3 \mathrm{ft} .6 \mathrm{in}$. in height of painted plaster forming the end of a small room; the sides also remained for a short way, but after a few feet were ruined. A portion of the mosaic floor was still in situ, some of which we raised. We also succeeded in rescuing in fragments from the earth the various parts of a small but interesting painting in tempera, which had formed part of one of the side walls, and had fallen inward when the walls gave way. The ground colour of the wall was red, with the picture, and probably others at intervals, inserted in a purplish border. The lower part of the wall was occupied by a "dado" of black relieved by small coloured patterns, and between the black and the vermilion ran a small frieze of alternating winged human faces and T-shaped ornaments on a yellow ground.

On February 10th one of the workmen on the carretera discovered six amphoræ underneath one of the tile graves, four of which he succeeded in extracting whole, and which we bought of him for 12 pesetas, together with three shallow dishes of coarse pottery. The amphoræ were apparently of a smaller size than those on whose handles we observed stamps, and had nothing on their handles. The bodies were nearly spherical, and the amphoræ much resembled that figured in $\mathrm{pl}$. d'agg. L. of the Annali dell' Instituto, vol. 50, 1878, in illustration of an article by Dressel on the M. Testaccio in Rome.

After we had left Peña de la Sal and were at work on 
another site, we heard of further discoveries on the carretera, so proceeded thither to investigate. We found that there had been found a leaden coffin. It lay apparently east and west, was devoid of ornament of any kind, and had contained nothing when first discovered. There is an ornamented one from Italica in the Museum at Seville.

\section{The River from Peña de la Sal to Alcolea.}

\section{Right Bank.}

December 15th. There is in this part only one despoblado of importance, namely, that of Hoyos de $S$. Sebastian, a farm on the bank of the river, about half-way in a direct line. Here there are vestiges of wall constructed of potsherds visible in the face of the bank and a large extent of tierra de villar. We give some handles from this site (79-89 and probably 129-126), which bear considerable resemblance to those from Pena de la Sal.

Between Peña de la Sal and Alcolea, but at a little distance from the river, are the ruins locally known as Las Torrecillas (see photograph, page 274). 'Ihey consist now of shapeless masses of brick-faced concrete masonry, scattered about in apparent confusion near the road. They seemed to have formed part of a large building, possibly thermæ, since there remain the ruins of an aqueduct, traceable at intervals for some $4 \mathrm{kil}$,, which apparently supplied it. It is, however, difficult to state the object of a building whose plan could only be revealed by excavation; this we were unable to carry out.

On following the above-mentioned aqueduct towards its source, it is found to be at first raised above the present level of the ground on a wall of concrete. The specus is merely represented by the bottom thereof, which was lined with flat bricks of the dimensions usual in this part ( 29 by $23 \mathrm{~cm}$.). Farther on its track is only marked, and that at intervals, by the spots where the plough had not been able to pass, owing to the obstruction presented by the foundations. We then lose sight of it altogether, after following it for about 1 kil., for about the same distance, after which we come upon it again, this time as a cut in the soft rock and containing running water, which supplies the huerta of Las Lumbreras. Its further 
course is underground, and marked at intervals of 50 to $60 \mathrm{~m}$. by "lumbreras" or air-holes of varying depth, but gradually deeper as we ascend the hill. These holes are now mere pits covered with brushwood and often partly choked with rubbish, but originally they doubtless were clean-cut shafts. We lose them at last, and this time finally. The aqueduct appears to originate, not in any spring as usual, but to collect water by filtration from the rock during its underground course. The water supply of Carmona, which also appears to be Roman, is collected in the same way.

II. Left Bank, from Peña de la Sal to Alcolea.

January 27 th. The first site is a small and inconsiderable despoblado which we call Villar de Mejia to distinguish it from a larger one close at hand, which will be found on the map as Mejia. In the first there is nothing but tierra de villar; in the second, besides about 800 metres of this, there is some extent of wall of potsherds. In this second site we collected amphora handles with the following marks.

$$
\mathrm{T} \cdot \mathrm{FANN}(99,97,100)
$$

LME (98).

The whole of the next sweep of the river as far as the mouth of the Corbones contains no Roman sites, and indeed. the river has shifted so much at this part that all this side of it is waste land. Arrived at the junction of the Corbones with the main stream, we ascend it for about $2 \frac{1}{2}$ kil. to the farm of the Real Tesoro, where are traces of a large Roman settlement, though nothing to indicate one as large as a town. The ground is covered with fragments of stone, tiles, pottery, \&c., but the only vestige of any construction which we could see was on the opposite side of the Corbones, where the fountain which still supplies the farm seems to be raised on Roman foundations.

Some 6 kil. farther up this stream is the despoblado of Angorillas, of considerable size, according to report, and the place whence came some portrait statues now at Carmona. But as we did not risit it on the present occasion, we cannot describe it more minutely than that there appears to be a hypocaust exposed.

March 25th. Returning now to the main stream, we 
come upon three despoblados in quick succession-Cortijo de Juan Barba, Adelfa and Guadajoz. The first-named is perhaps of the greatest extent, and vielded handles which bear the stamps 192-197; of these, LSPBoEQ $(192,3)$ occurs again in Rome and in France (C.I. L., XII, 5683, 261). Adelfa is smaller, and Guadajoz, again, of a larger size. The latter contains some walls, though in a very ruinous condition. We got the mark II SER (No. 1) from this spot. Below Guadajoz the river, which is here much reduced in volume owing to the short cut of the Sairon produced by a flood about forty years ago, has, so far as we could see, no Roman sites on its banks.

Alcolea del Rto.

Some excavations here were undertaken during the time when work was stopped at Peña de. la Sal (December 15 th-21st.)

The most conspicuous object on the Mesa de Alcolea is the "Bola" (see photographs and plan, \&c., 10). This seems to be a "castellum" or reservoir for distribution of water to the town. It is of concrete, dome-shaped, with a circular aperture at the top, the whole resembling to a certain degree, both in shape and material, Agrippa's Pantheon in Rome. It is faced externally with opus reticulatum, and internally with similar blocks of stone disposed in horizontal layers. There are two large holes broken in the side, and a large portion of the floor is gone, otherwise the builling is in fair preservation. It owes this comparative immunity to the fact that till within recent years the building was used as a chapel, and was thus protected from violence. This is doubtless the reason that during the excavation of the rubbish in the days December 19th, 20th, 21st, an azulejo or enamelled tile of early type ras found and fragments of two or three others.

On one side of the Bola project the remains of the first stage of the distributing pipe. It consists of two similar blocks of stone with a channel cut in each. When in position one was reversed on the top of the other, and a massive pipe thus formed. In the lower and longer stone, which was nearly in situ, we found the slot which 
PLAN 10.
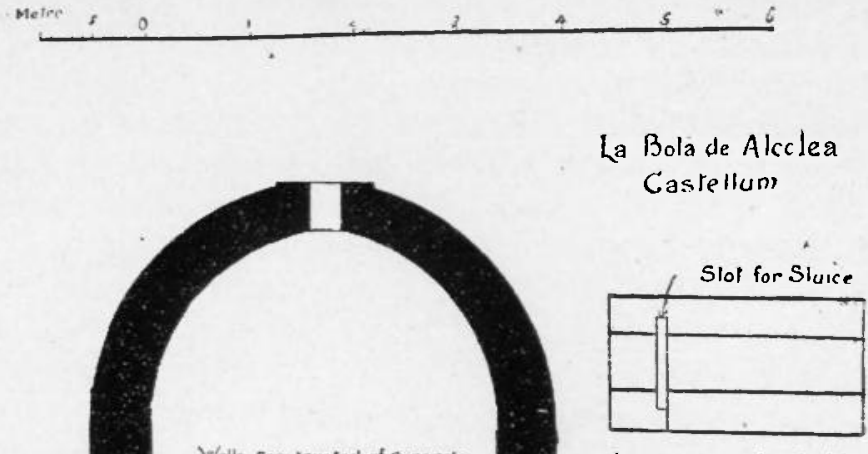

Walls constructed of cons rete.

faced externally wilh opas

reticulatum. infernally willy

Lower stone for Ourlek.

sigitar stones ily horizoistal

Double Scale

layers covered with bard

water cemen

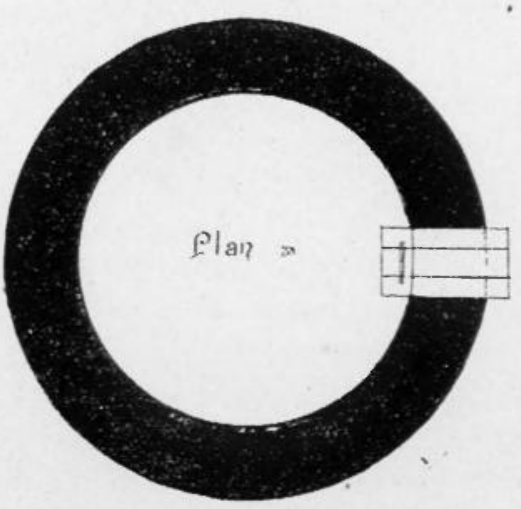


was intended to receive the sluice which regulated or stopped the emission of water from the "castellum."

The rest of our time was employed in making somewhat fruitless trials in various parts of the ground. In most cases we came upon the old level at a very small depth, such as a couple of feet. At so shallow a depth, it was hardly to be expected that well preserved remains should be found, and, in fact, everything was very much destroyed. The Mesa of Alcolea is divided into a number of small holdings separated from each other by imaginary boundary lines, often a matter of dispute between the owners themselves. As some of these small owners had given us permission to dig and some had not, we several times found ourselves unconsciously trespassing, and had to retire and pacify as we best could the irate owner.

The river has made, and is still making, great inroads on the Mesa, the cliff of clay and alluvial soil on which the town originally stood is being gradually swept away, and probably the present does not cover more than onehalf of the former extent of the site. The reason for this destruction is most probably to be sought in the erection by the Moors of the great dam across the river, in the construction of which they probably made use of the old river wall, thus at once depriving the bank of its former protection, and causing the current to impinge more directly on the site than heretofore. This destruction of the higher ground has probably led to the migration of the town to its present position higher up the stream and on lower ground, and possibly also to the establishment of the "new town" of Villanueva, a mile or two down stream from Canana.

The river wall to which allusion has just been made in part still exists above the dam, and at the lowest part of the modern town. It now consists of a " battering" face of concrete nearly 20 feet high and about 40 feet long, which, smooth in front, but curiously formed into steps behind, after this fashion, though whether it was originally backed with stone, since removed, or was given this shape in order to obtain a better hold of the

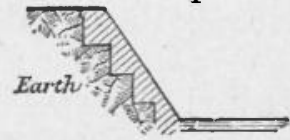
earth behind it is not clear. 
The River from Alcolea to Alcalà del Rio.

I. Right bank, between Alcolea and Cantillana.

This contains but little. Below Alcolea we follow the high barranco of the Mesa to Villanueva, which has been hitherto identified with the ancient Canana. But as I think we have shown subsequently (p. 287), this is an unfounded assumption, and Villanueva contains nothing lioman, except a very few stones which may well have come from the Mesa de Alcolea. The church, which we visited in search of inscriptions, has none, and we were unable to obtain any information as to C. I. L., II, 1076, which Bravo states to be in Villanueva.

There is a small despoblado about $1 \frac{1}{2}$ kil. from the town on the river Viar, but only a small one, called Estacada de las Minas. Some 8 kil. farther is a somewhat more considerable one, La Loma de Villa, with some remains of building, and the following inscription :

$$
\begin{gathered}
\text { I) } \mathrm{M} \$ \mathrm{~S} \\
\mathrm{M} \cdot \mathrm{AVRELIVS} \\
\text { CEMERVS } \\
\text { VIXIT } \cdot \text { ANNIS } \\
\text { XXXX } \cdot \text { III } \cdot \text { MEN } \\
\mathrm{V} \cdot \mathrm{DIES} \cdot \mathrm{VII} \cdot \mathrm{PI} \\
\mathrm{VS} \cdot \mathrm{IN} \text { SVIS } \\
\mathrm{H} \cdot \mathrm{S} \cdot \mathrm{E} \\
\mathrm{S} \cdot \mathrm{T} \cdot \mathrm{T} \cdot \mathrm{L}
\end{gathered}
$$

(Unpublished.)

Reiurning to the main stream, and following it, we come upon nothing till we pass the mouth of the river Huesna (or Guesna), on the heights beyond which are the remains at Villartilla of the ancient Oducia, which has hitherto been without a local habitation, but has occasionally been lodged at Tocina, of which more afterwards. To judge from Mr. Bonsor's description, who, alone, visited the spot after my departure, there are considerable remains here, and as fair a site for excavation as at La Peña de la Sal. He mentions aqueducts, baths, 
reservoirs, "and a great building with several rooms which I think may prove to be thermæ. Columns, inscriptions, mosaic pavements, coins, everything has been found, and is still found there." There appear, however, not to be any remains of a quay, such as we would expect from the example of Caintillana. I have given below (p. 288) the reasons which lead me to look for Oducia about this point; and Mr. Bonsor's discovery comes as a happy confirmation of my theory.

The bank between Villartilla and Cantillana contains not one single despoblado, unless we count a doubtful one near the ferry towards Tocina.

II. Left Bank, between Alcolea and Cantillana.

This is also a very unproductive stretch of river for the archæologist. Starting from Alcolea, we follow an old bend in the river to Los Villares, where is' a despoblado of some little size. and where we picked up a handle with the mark AVG (145). Continuing, we find nothing as far as Tocina, a town which has sometimes been believed to be the site of Oducia. . This, however, it cannot be, as (1) it is not, and apparently never was, on the river; (2) it contains, so far as we could see, no Roman remains whatever, less than even Villanueva. 'The name however, may be an echo of the departed Oducia (see p. 287). One kilometre west of Tocina is the IIuerta de Cristo, a despoblado with tierra de villar. It may be from this site that the inscription C.I. L., II, 1265, was brought. It is the funeral inscription of one Fabius Aurelianus, and is described as coming from Tocina, from the Santo Cristo de la Vera Cruz to Seville, where it now is. From this point to Cantillana there does not occur within our observation a single despoblado.

\section{Canana, Oducia, Nevia.}

These three towns are mentioned together in an inscription (C. I. L., II, 1182) first given by Caro as existing at Seville, near the Puerta de Carmona. It now appears to have entirely disappeared, and was not seen by Hubner. It runs as follows :- 


$\mathrm{C} \cdot \mathrm{AELIO} \cdot \mathrm{C} \cdot \mathrm{F} \cdot \mathrm{C} \cdot \mathrm{N}$
QVIR $\cdot \mathrm{AVITO}$
LYNTRARIORVM $\cdot$ OMNIVM $\cdot$ PATRO
NO $\cdot$ LYNTRARI $\cdot \mathrm{CA}$
NAMENSES $\cdot$ ODVCI
ENSES $\cdot$ NAEVENSES

L. 3, 4. LYNTR. leg. LTNTR.

L. 4, 5. CANAMENSES, leg. CANANFNSES. $C f$. Alcolen.

L. 6. NAEVENSES, correxit tacite $\mathrm{H}$.

It is the dedication of a statue to C. Alius Avitus by the lightermen of Canana, Oducia, and Næva, The word "lintrarii," which occurs here, is a very rare one; besides this instance I have only been able to discover one other instance of its use (Ulp. Dig., 4, 9, 1, § 4), though "linter" is, of course, considerably commoner. We may therefore not unreasonably conclude that it has some special significance in the present case, and the meaning which seems most appropriate to the various instances of the use (exclusive of the poets), of "linter" and "lintrarius" is that "linter" is a large flat-bocomed cargo-boat (what is called a lighter on the Thames), and "lintrarius" a man who navigates such a boat, which must have somewhat resembled the "barca" in use to.day as a ferry on the Quadalquivir. That such boats should have been in use in Roman times is in itself extremely probable, to convey the cargoes of the sea-going ships which arrived at Ilipa (Alcala del Rio), ${ }^{1}$ up to which point the tides reached, to the towns higher up the river. One fact follows at once from this determination of the meaning of "lintrarius," namely, that the towns Canana, Oducia, and Næva must have been situated actually on the banks of the river Bætis; further, that in all probability they were situated above the limits of the tide, i.e., Ilipa. We may also assume from the fact of the three guilds of lightermen thus making a joint dedication, or perhaps speaking as but a single corporation, that the towns were situated together, and probably close together.

Taking now the first of these names, Cananenses, we find the site already well identified. The various inscrip- 
tions collected by Hiibner under the head of Cariana, though erroneously attributed by him to Villanueva del Rio, and still more, the inscription of Thacius found and removed to Carmona in 1888 , prove beyond reasonable doubt that the site of Canana is to be found at the modern Alcolea del Rio, or rather just below the town on the height called La Mesa de Alcolea. There are still remains to be seen of the old concrete river wall just above the town (destroyed by the current lower down), built somewhat in this way, about 20 feet high :-

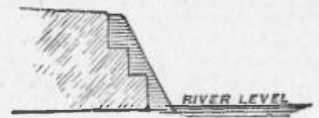

This may be part of the wharf to which the lintrarii would bring their freights, but in the presence of so few fragments, and so imperfect, it is better perhaps not to speak with certainty.

The next town, Oducia, presents greater difficulties in identifation. An echo of the name may linger in the modern Tocina, but beyond all doubt the modern town does not occupy that, or indeed any, ancient site. Indeed, were there signs of Roman occupation, as there are not, the position would preclude any identification with Oducia, as it is not on the river, but at some distance from it, nor does the stream appear ever to have run much nearer than now.

If we leave the question of the position of Oducia for the moment undecided and pass to the consideration of that of Næva, we find more help. Starting up stream from Alcala, the first Roman remains of any importance which we come across are to be found at Cantillana, where is to be seen, besides an aqueduct, which carries an abundant supply of water to within a short distance of the town, and a large number of fragments of columns, \&c., scattered through the town, a large collection of debris of concrete walling, with one or two pieces yet standing, though the whole is so much shattered as to make the plan irrecoverable. This evidently was a place of some importance in the way of shipping, as the ruins of the port show, and as it is the first place above Alcala which has such signs, we may not unreasonably conclude 
that Cantillana occupies the site of the ancient Næva. The inscriptions which preserve the name of Næva are unfortunately not conclusive in determining the position. Besides the one prefixed to this section there are two at Seville in the museum, without indication of their provenance, ${ }^{1}$ and another in a private collection in the same city, said to have been found "not far from Cazalla de la Sierra," an obviously inconclusive notice, since we have already seen that Næva must have been on the river.

The inscriptions found at Cantillana prove nothing.

We thus limit the range of river within which we must place Oducia to the part between Villanueva above and Cantillana below. The former place is excluded by (1) its name; (2) its proximity to the "Mesa de Alcolea"; (3) its entire lack of Roman remains, with the exception of one funeral titulus from the neighbourhood. Huibner, it is true, identifies it with Canama (sic), but this was without personal observation.

The inscriptions of Oducia are lamentably few, consisting (except that of which we are now treating) solely of one, "Cornelia, l. f. Rustica . Oduciensis . Huic Ordo . . ." said to have been seen, now in Lora del Rio, now near Italica. It thus proves nothing.

There is a place called Cortijo del Indio, on the right bank of the river some little way below the railway bridge of Tocina, which has, so far as could be discerned from the other side of the river, remains of concrete constructions near the water's edge. In default of a more definitely indicated site, it would do very well as the position of Oducia, as it is sufficiently near the present Tocina to account for the transference of the name when the modern town was built.

If this be so, the three towns lay at about equal distances apart, on the right bank of the Brtis, and formed a distinct division on the river between the tidal and upper waters, in which the carrying trade was performed in large flat lighters. This distinction would appear to have been kept up to some extent even in Moorish times, for to the present day, while every town above Alcolea has its Moorish dam, extending across the

\footnotetext{
1 One (C. I. L., 1166), has the notice, "Encontrado en la calle de la Compania," which proves nothing.
} 
river and effectually barring the progress of boats, there is no such obstruction either at Villanueva, Cantillana, or Alcala, or at any point below Alcolea, thus showing that it was at least possible for such a trade to have been carried on.

Since writing the above, I have been informed by my friend and colleague $\mathrm{Mr}$. Bonsor that ruins which probably indicate the site of Oducia are to be seen, not at the Cortijo del Indio, "but 4 kil. from there down the river in the direction of Cantillana, near the union of the river Huesna to the Guadalquivir. . . . The place is called Villartilla, which seems to suggest some ruins." (Villar, as well as Castillejo, Torreon, \&c., is a common word to designate a Roman site- "tierra de villar" meaning earth with bricks, potsherds, \&c., in it.) "These are still existing in comparatively good condition. They are mostly water works . . . and a great building with several rooms, which I think may prove to be thermæ."

We thus transfer the site of Oducia from Cortijo del Indio to Villartilla, a little lower down the river.

III. From Cantillana, to Alcala. Right Bank.

In this stretch there is very little. In fact, the nearer we approach Seville, the more thinly are the despoblados scattered, and the more considerable appear the towns to have been.

The first and indeed the only indisputable despoblado to be met with on this side is found soon after passing the river Viar, a task of some uncertainty on foot, if the river be swollen by recent rains, as was our case. It is called El Cortijillo, and besides the usual tierra de villar contains only a shapeless mass of concrete about 3 feet high in the middle of a field. We next come to Villaverde, which is, for archrologists at least, a modern town, and contains no Roman remains. Beyond this is the "Cañaveral," an immense plantation of reeds, which makes it an impossibility to keep to the river bank, but this is of the less consequence, as a low-lying tract like this is found, in our experience, never to yield any Roman sites. The country onward from here to Alcala is dreary in the extreme, and contains no ancient remains and but two modern farms in its whole extent.

IV. The Left Bank, from Cantillana to Alcala. 
April 9th. The case is somewhat better on the left bank, but even here there is not much. From Cantillana, as far as Brenes, there is nothing, as is the case with that. town itself. On its outskirts, however, we find three masses of concrete, apparently the remains of arches which once carried an aqueduct, called El Callejon, and just beyond it a despoblado of tierra de villar. Just beyond the mouth of the Bodegon arroyo there is a despoblado of considerable size, called El Villar de Brenes by us, which seems to have had potteries, to judge from the large accumulation of refuse. We obtained from this spot marks (199-203) among them

HERMES (199) ISHERME (200) QVCVIR (203).

A little way lower down, just beyond the barqueta or ferry, is a smaller despoblado of tierra de villar, called La Cruz Verde. From this point onwards to Alcala there is nothing. The earlier part of the way, indeed, was perhaps rather perfunctorily performed, being an enclosure of a bull-breeder and rather dangerous as late as the month of April.

\section{ILIPA.}

Surnamed "Magna," to distinguish it from other towns of the same name (Ptolemy, 2, 4, 13).

For the identification of its site we have two very trustworthy pieces of evidence:-(1) That up to Ilipa sea-going vessels of light draught plied (Strabo, III, 3, c. 132); (2) the story of the remarkable spring-tide observed by Seleucus at Ilipa (Strabo, III, 5, § 8).

'I'hese two references taken together would seem to prove (1) that the tides were appreciably, and occasionally strongly, felt at Ilipa; (2) that they were not felt much above that place, since it was the limit of the smaller sea-going ships.

Turning now in search of some Roman site to which the tides extend, and beyond which they are not felt, we find that at Alcala del Rio is the present limit of the tidal water, further, that there are very considerable remains there of Roman walls and of Roman pier- 
construction ; therefore, with Carrillo and others, ${ }^{1}$ Alcala may be identified with Tlipa with the utmost confidence. ${ }^{2}$

There is a curious delusion prevalent in some quarters, and more especially among the natives of the town, that Penaflor is the modern representative of Ilipa. The idea, I believe, was started by Rodrigo Caro, but the reason for it I have never been able to discover.

The error has found its way into Murray's Guide-book, the confusion being increased by a misprint of Ilissa for Ilipa.

Alcaria DeL RIo.

This town was visited by us on April 10th and 11th, but no excavations were undertaken, as well on account of the lack of time and money as because the modern town occupies the same ground as the ancient Ilipa, thus making excavation a matter dependent on a large expenditure for compensation.

The city owes its present name, as does also Alcolea, to the Arabic equivalent for castle, thus indicating that both these places were considered strong defensive positions. In the case of Alcolea, however, the inroads of the river have led to the abandonment of the higher position and the removal of the town to the present lower site. Alcala, better defended, or not so much exposed to the attacks of the stream, has continued to the present day in its original position.

There are abundant traces of Roman work to be observed throughout Alcala, but the chief points of interest are the Roman walls, which yet exist to a considerable extent, and the Roman quay, which is unfortunately so much broken by the undermining action of the river that its original plan is not now recoverable.

Plan 11 also gives the ground plan of these walls and towers, showing some curious projections on the inner side which I believe to have served originally as supports to arches which carried a broad walk round the top of the wall. Each tower was also divided into two parts; but

1 Alf. Carrillo. "Discurso geografico sobre que Ilipa magna no es Penaflor, sino Alcala del Rio." (Read before the Madria Academ5, 1743; mentioned by Hübner, C. I. L., II, p. 141.)
2 For the coins of Ilipa (mostly found at Alcala), see Eckhel, 1, 22 Delgado, 2,100 , plate xxxvii. 
the upper storey having now gone, it is difficult to reconstruct the original building in its entirety. (See in

PLAN 11.

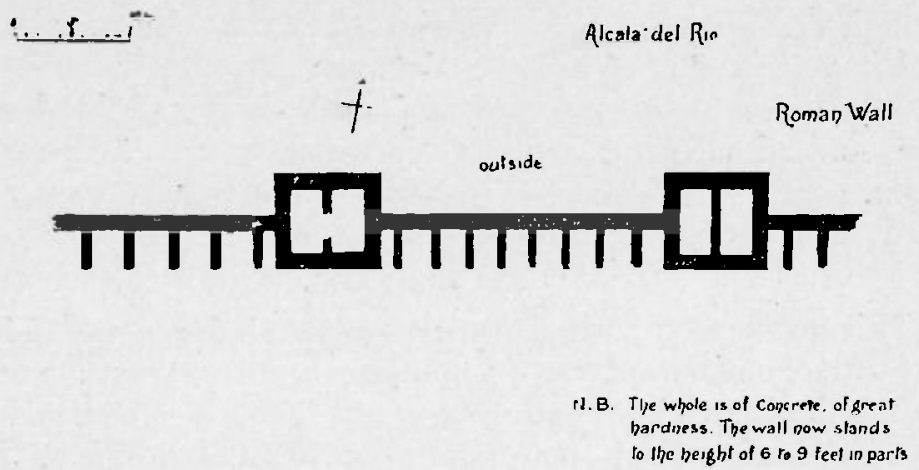

illustration to this Encycl. Brit., art. " Rome," Fig. 25, plan of part of Aurelian's wall. Piranesi, Ant. di Roma, I, tav. 8,2 .)

There are also at Alcala in the Plaza foundations of Roman buildings to be seen; but their plan is not to be made out.

As regards inscriptions, our experience was that of Hübner, who writes, " titulos inveni pæne nullos." Besides C. 1. L., II, 1089, the inscription of Dasumia, the only one which Hübner copied, we only saw one other, and that an unintelligible fragment.

\section{OPCI}

The River hrom Alcalì to Sevilde.

I. Right Bank.

There is but one despoblado, Las Arenas, between Alcala and Santiponce (Italica) situated on a slight rise, which may be the ancient bank, rather more than half a kilometre from the present. The wretched town of La Algaba contains a fine Moorish tower, but no Roman remains ; thence to Italica there is nothing.

Italica itself has furnished too many an occasion of moralising to guide-books and travellers' diaries to need particular description here. Suffice it to say that the 
plan given by Demetrio de los Rios shows more of the walls than can at present be seen except in the north and north-west parts, and that the projection towards the south-east is not now to be traced. It seems to have been a quay of like nature to that at Alcalia.

Hence to Seville is flat, aud contains no site.

II. Left Bank.

This is flat and desolate the whole way and does not contain a single despoblado. Probably the liability to flood acted as a deterrent in this part of the river, except on high sites, as Villar de Brenes.

\section{ITALICA.}

On the site of this well known town little need be said. It was Ambrosia de Morales who first pointed out that the ruins of Santiponce were not those of Seville, as had been previously supposed, but of a separate town, and that town Italica. In his day the name yet survived in a somewhat altered form, the fields in the neighbourhood being called "Los Campos de Talca" ( $v$. Hiibner, C. I: L., II, p. 146). Since the time of Morales, various investigators have made excavations on the site, tempted thereto in great measure by its proximity to Seville and the prominence of the ruins of the amphitheatre. Among the first of these was the monk Jose Moscoso, who in $\mathbf{1 7 9 9}$ laid bare and enclosed with a wall a large pavement of mosaic, now, unfortunately, ruined by exposure to the weather.

Since that time the most important work on the site has been the following:--The excavation of the thermæ by D. Demetrio de los Rios in 1860 (see Annali dell' Inst. 33,1861 , p. 375 seq.). The amphitheatre (in part) by the same, 1862 (Memoria arqueologico-descriptiva del anfiteatro de Itálica, acompañada del plano y restauración del mismo edificio por . . . D. Demetrio de los Rios, Madrid, 1862). 'These have plans of the two buildings executed with great accuracy.

\section{Mvirgia.}

Though the site of this town does not, strictly speaking, lie on the banks of the Guadalquivir, but at a distance of 
some kilometres, yet it may well be included in the present account, since the stream on which it is situated, the Guesna, ${ }^{1}$ is a tributary of the Guadalquivir.

The town of Munigua is not mentioned in any ancient author, and its existence was unsuspected till the expedition of Cortes, referred to subsequently, published in the Mem. Acad. Sevill., 1773, revealed the former existence of the town at the place now called Castillo de la Mulva. Another expedition was made about the same time by Guseme of Lora, but since that time the site appears not to have been visited by an archæologist.

The inscriptions found on the occasion of Cortes's visit (C. I. L., II, 1049, 1050), as well as another not mentioned in either account, but extant in the museum of Seville, and described by Hiibner as " reperta una cum 1049, 1050 ," leave no doubt that this was the site of Munigua, a town of some importance, since in the reign of Titus it was a municipium, and that too, not of Flavian creation, as the absence of "Flavium " or "F." would lead us to infer (C.I. L., 1051).

An account of a visit which we made to the Castillo de Mulva on January 10th will be found in the following pages. I have thought it worth while to describe it at length, as it may perhaps give some notion of the character of the country in which it is situated-a character which is shared by the whole of the outskirts of the Sierra Morena, but where, with this exception, we found no traces of Roman occupation.

As will be seen, we are able to bear witness to the continued existence at Mulva of inscription 1050, to which Hiibner appends the note "videtur periisse" in the Corpus. Nos. 1052, 1053, we did not see, but, as Hibner says of them, they may still be there.

On the 10th of January, 1890, we left Carmona by the 4 a.m. train for an expedition to Malva and its vicinity, and arrived about eight at Villanueva de las Minas, where we got out. Inquiring for an arriero, who might provide donkeys or so, we found that such a thing was not obtainable, but gained the information that Mulva was close to Arenilla, the next station on the line-a hint for 
future expeditions. So we started to walk along the line (7 kil.). The scenery here was quite different from the country below, as we were now in the outskirts of the Sierra Morena. Cultivation was only represented, and that sparsely, by a few olive fields in the distance. The whole landscape was composed of low rounder hills covered with a dense growth of myrtle, dwarf willows, tall rosemary, and stunted holm oak. A few stone pilies and holm oaks stood up among these, but the country could not be called wooded. Among these hills were one or two streams, also a difference from the Vega and Carmona-clear running brooks with stony beds. We crossed the largest of these, the Guesna, on a very narrow iron railway bridge.

We eventually came to Arenilla, and from a few yards beyond it Mulva is well seen in the middle of the valley below. We now struck straight across through the scrub, for it passes a tributary of Guesna. We reached it at ten. The castle is situated on a small eminence, surrounded by this stream, steep by nature and apparently made more so by art, on the top of which rise the walls. These consist of concrete, with bands at intervals of brick. Frequent buttresses, the majority of which have now disappeared, protected them from any thrust, and these again seem to have had subsidiary buttresses near the foot. The walls on the west side are the best preserved. The castle is roughly rectangular in shape, the length being from north to south, and had the entrance on the east, facing the tower. The probable site is marked by a semicircular recess. Inside the castle there are remains of later construction, though still, I believe, Roman. Of these the most remarkable is the north wall of a room, which is ornamented on the inside with an arcade of three arches. There are also, at the south extremity of the castle, remains of two constructions, lined with cement, and apparently intended as receptacles for storing water.

On the lower slopes of the east side of the hill on which stands the castle were found the various inscriptions mentioned by Cortes and Guseme (op. cit.). Of these we found one still existing (C.I.L., II, 1050, Hiibner, "videtur periisse"). The other two mentioned by 
Guseme may be there still, but we failed to see them. Here also are ruins of Roman masonry. One is a chamber or passage, about 20 feet long, 3 feet wide, and 12 feet high, the original use of which it is difficult, without excavation, to decide.

On the level ground at the foot, and for some distance, are abundant traces of Roman occupation in the shape of squared blocks of granite, fragments of concrete, drums of columns, bricks, and tiles without number. The tiles which we found here, as well as the bricks, and the few fragments of amphoræ which we saw, are of a totally different clay to those at Carmona, Peña de la Sal, or Alcolea, being red, sandy, and full of mica, whereas those are yellow, without sand or mica. Where were they made? There seems to be no clay in the immediate neighbourhood.

Of the scoriæ mentioned by Cortes as abundant we saw none; but in a site which in parts is densely covered with undergrowth it is not easy to see everything. Nor, again, could we find the subterranean excavation called "La. Miua" (ib.). But the somewhat remote position of Munigua (doubly so at the present day), and the mineral wealth to be found at Pedroso, about nine miles farther on, make it seem probable that the origin of the town was connected with mines. Munigua was a municipium and acquired the surname Flavium, but probably not from the Flavian emperors.

Leaving the Castillo about 2.30, we went back to the railway, and followed it towards Villanueva, about halfway, when we struck off to the right or westward towards the Serro de la Encarnacion, a commanding hill about two miles off. We could see, from the railway, buildings on the top, and we had heard wonderful accounts of the remains to be seen there-castles, halls, underground chambers, and what not. These accounts, indeed, we considered to be thoroughly untrustworthy; but this was an opportunity which we were not likely to have again of discovering the truth, if any, which underlay them. We therefore made our way to the base. The walking was very bad-through brushwood as high as a man and abounding in thorny plants. A short but steepish climb brought us to the top, where at first we 
discovered nothing, but later on we came across some rocks, which made us think that we had mistaken natural formations for buildings. However, on the farther edge of the plateau we found the remains of a castle, alas! not Roman, but Moorish, being made of tapia, with strengthening quoins of brick and rubble masonry. There was also at a little distance south the remains of apparently a church ( $c f^{3}$. the name of the hill), of somewhat similar construction. Not a vestige of anything Roman was to be seen. But though we were disappointed in the object of our search, the situation was magnificent. The plateau here ends in a sheer precipice to the north and west, separated by some convulsion of nature from a similar though lower crag on the adjoining hill. At the bottom of the gorge thus formed runs a small stream (the Parroso, or one of its feeders), which takes its course towards the Guadalquivir, in the direction of Tocina. The fortress is built on the very verge of the precipice, with a clear drop of some hundreds of feet to the bed of the stream beneath, and commanding a magnificent view to the south over the Guadalquivir, the Vega beyond, and as far as Carmona, which stands up well on its ridge. On a clear day the mountains of Ronda should be distinctly visible, but on this occasion we could not, see them.

At 4.40 we began the descent on the south-west slope and made our way over broken ground, through a pine wood and various olive fields to the Guesna, which we had to wade, and so through more olives and waste land to the railway and the station of Villanueva $y$ Alcolea, whence, after forty minutes' wait, we took the train to Tocina. There after some search we obtained a primitive meal, at a primitive posada, of fried eggs and native sausages, and oblained some, but not much, information as to sites in the neighbourhood. There seems to be nothing of antiquity in Tocina, but reports of remains at Villa verde, below Cantillana. ${ }^{\text {At } 9}$ o'clock we left and walked in the dark along the line to Tocina Empalme, whence we eventually got a train to Carmona, arriving just before midnight.

1 This was subsequently found to be untrue. 
$29 \varepsilon$ THE ROMAN TOWNS IN THE VALLEY OF THE B.ETS,

APPENDIX.

A. ADDITIONS TO C. I. L., II.

Celti.

Peñaflor, In domo Antonii Parias, literis magnis, sæculi, ut videtur, II ineuntis. (Cf. 2328.)

\section{IIIIII] VIP ; $A V[G$}

GVMGRA?

Ibidem ' encontrado en el sitio que llaman

Las Moncruas' ROMVLA $\cdot$ AN $\cdot$ XVI

$\mathrm{PI} \lambda$ IN SVLS

$\mathrm{H} \cdot \mathrm{S} \cdot \mathrm{E} \cdot \mathrm{S} \cdot \mathrm{T} \cdot \mathrm{T} \cdot \mathrm{L} \cdot \mathrm{D} \cdot \mathrm{M} \cdot \mathrm{S}$

Insolito loco positum est $\mathrm{D} \cdot \mathrm{M} \cdot \mathrm{S}$.

\section{AXatr.}

'En el cortijo del Membrillo, cerea de Setefilla termino de Lora.' In lapide, lit. quadratis $6 \mathrm{~cm}$. altis

DIVO ^ AVGVSTO

Ævi videtur Tiberiani.

\section{Canana.}

Repert a. 1888 en Alcolea ùel Rio. a. 1889 traslatum Carmonam, ubi servatur in museo

$\mathrm{M} \cdot \mathrm{THA}] \mathrm{CIO} \cdot \mathrm{L} \cdot \mathrm{F} \cdot \mathrm{QTR} \cdot \mathrm{LV}[\mathrm{PO}$

$\mathrm{HVIC} \cdot \mathrm{ORDO} \cdot \mathrm{MVN} \cdot[\mathrm{FL} \cdot$

CANANLOC $\cdot$ SEPV $[L T \cdot$

FVNER - IMPENS AM

STATVAM $\cdot$ PEDES $[$ TR

DE[CR]EVIT

L · THACIVS $\cdot$ IUPVS

PATER $\cdot \mathrm{ET} \cdot \mathrm{CORNE}[\mathrm{LIA}$

SECVNDA $\cdot \operatorname{MAT}[\mathrm{ER}$

$$
\mathrm{H}] \cdot \mathrm{V} \cdot \mathrm{I} \cdot \mathrm{R}
$$


Alcoleæ, in domo Camili cujusdam

[STA A

TVAM $\cdot$ EQVESTREM AVRATICIAMPONI

Ibidem, literis satis bonis.

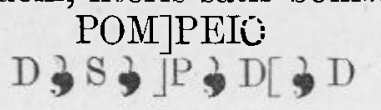

Alcoleæ, in limine domus Joannis Ricuero

... ERG - SENECIO literis evanidis

En la Loma de Villa, termino de

Villanueva del Rio

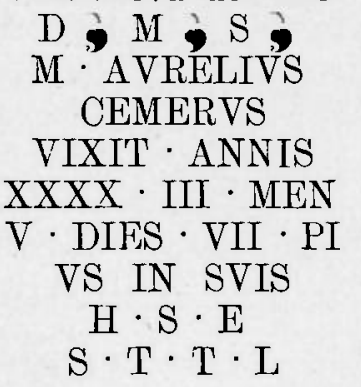

B. POTIERS' STAMPS ON AMPHORA HANDLES.

(The numbers in brackets give the number of duplicates of that stamp found in the same place.)

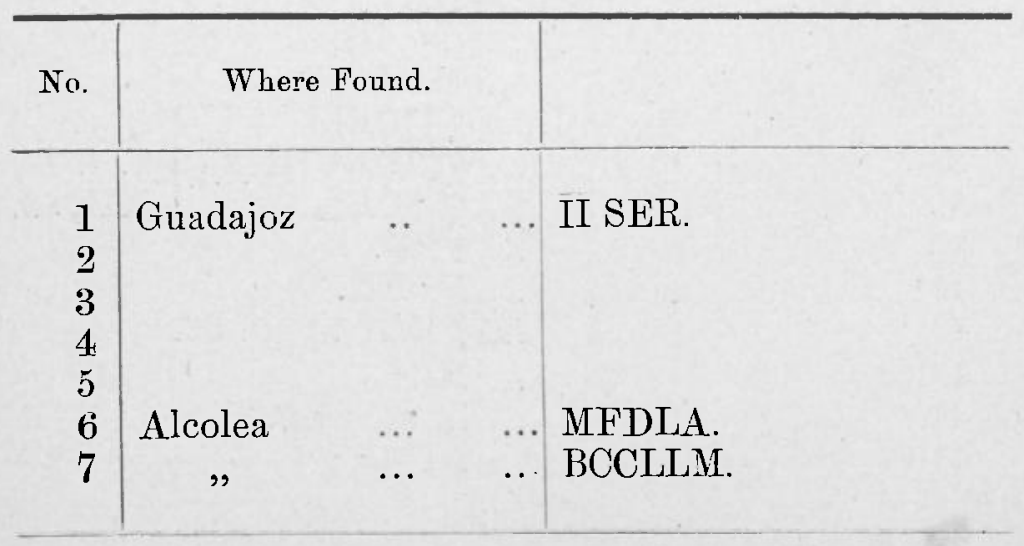


300 THE ROMAN TOWNS IN THE VALLEY OF THE BETIS,

\begin{tabular}{|c|c|c|c|}
\hline Vo. & Where Found. & & \\
\hline $\begin{array}{l}11 \\
12 \\
13 \\
14 \\
15 \\
16 \\
17 \\
18 \\
19 \\
20 \\
21 \\
22 \\
23 \\
24 \\
25 \\
26 \\
27 \\
28 \\
29 \\
30 \\
31 \\
32 \\
33 \\
34 \\
35 \\
36 \\
37 \\
38 \\
39 \\
40 \\
41 \\
42 \\
43 \\
44 \\
45\end{array}$ & $\begin{array}{l}\text { " } \\
" \\
" \\
" \\
" \\
" \\
" \\
" \\
" \\
" \\
" \\
" \\
" \\
" \\
" \\
" \\
" \\
" \\
" \\
" \\
" \\
" \\
"\end{array}$ & 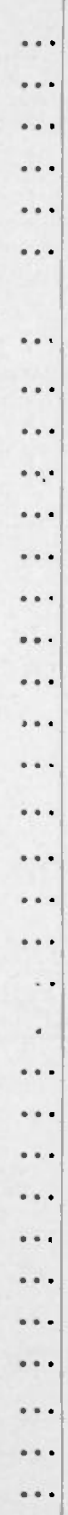 & 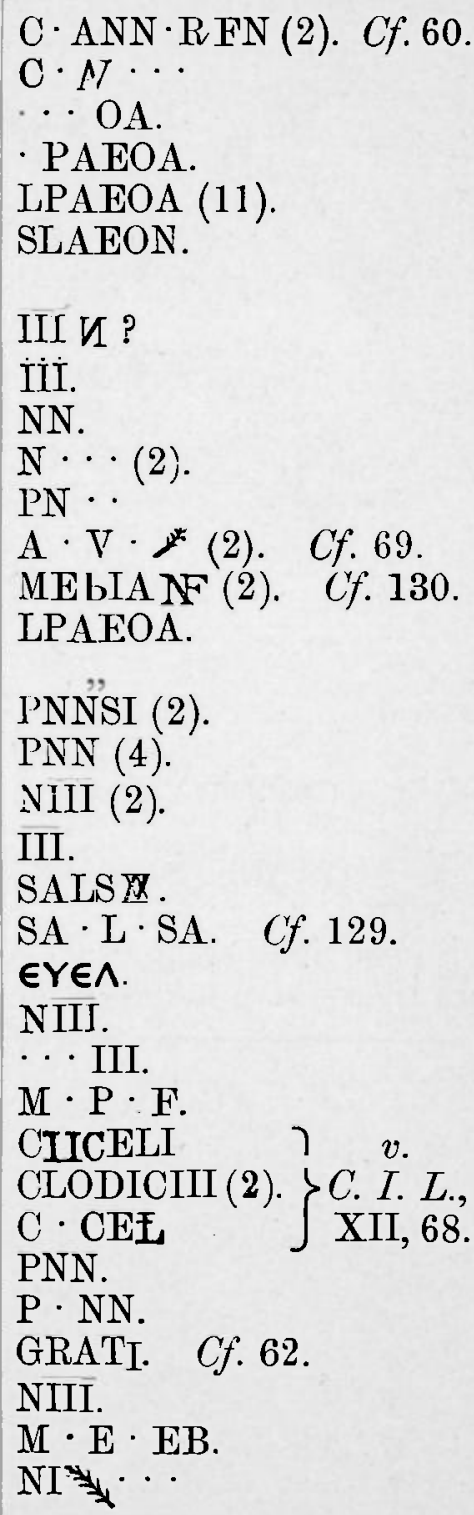 \\
\hline
\end{tabular}




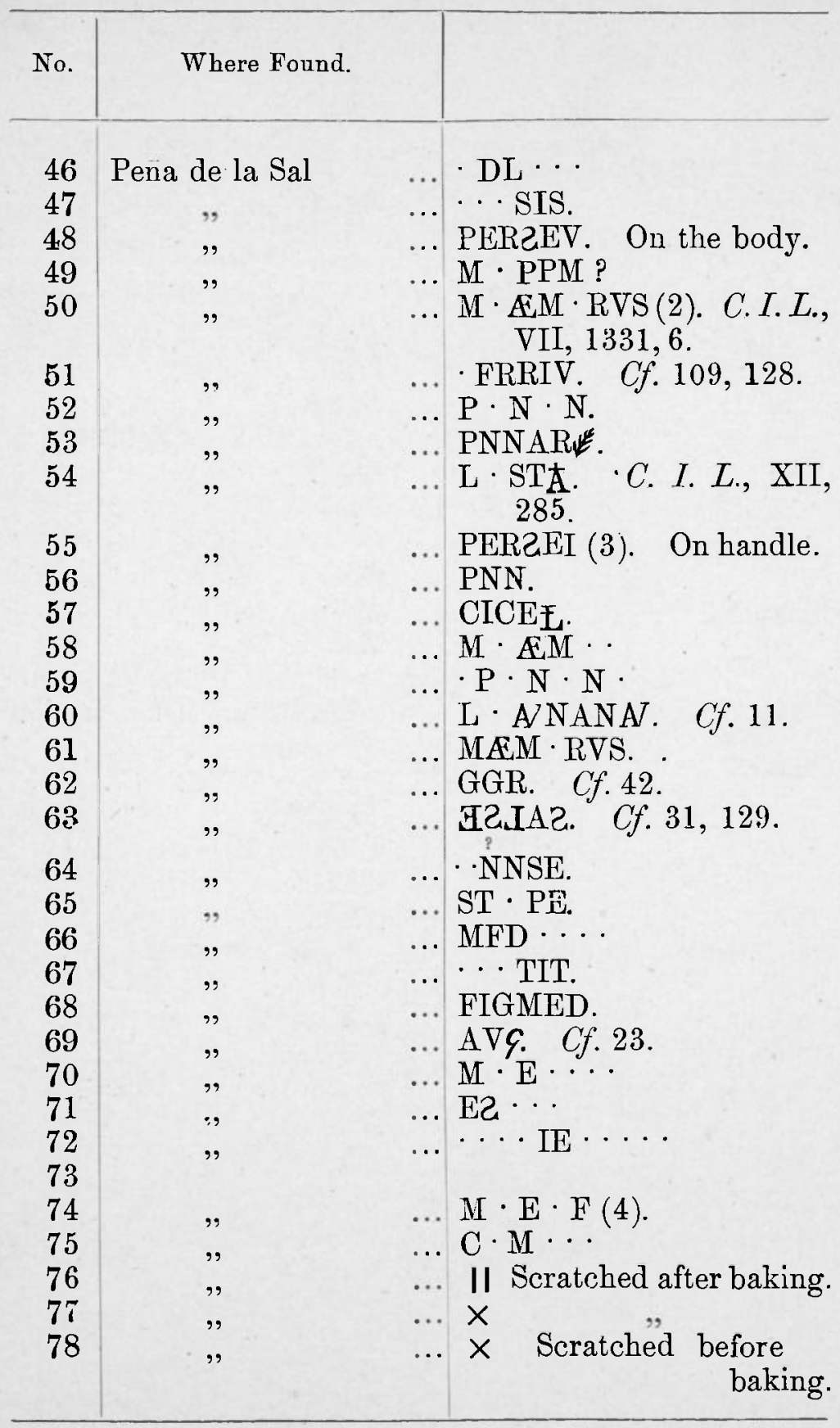


The roman towns in the Valley of the B etis,

\begin{tabular}{|c|c|c|c|c|}
\hline No. & Where For & und. & & \\
\hline 79 & Hoyo de S. Se & ebastian & & $M \cdot C \cdot S$ \\
\hline 80 & , , & & $\ldots$ & MCSP. \\
\hline 81 & 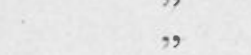 & & $\ldots$. & $\operatorname{PNN}^{2}(7)$. \\
\hline 82 & 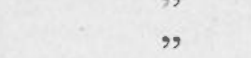 & & ... & PNN. \\
\hline 83 & " & & $\ldots$ & CLMM. \\
\hline 84 & 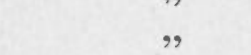 & & $\ldots$ & ...W.IIO. \\
\hline 85 & $"$ & & ... & DEF. \\
\hline 86 & 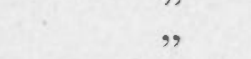 & & ... & CLLM. \\
\hline 87 & $"$ & & $\ldots$ & $\cdots$ PIIII $\quad C f .113$. \\
\hline 88 & 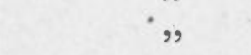 & & ... & $\mathrm{Q \nabla \Lambda} \cdots \cdots$ \\
\hline 89 & & & ... & $\mathrm{F} \triangle \mathrm{F}$ \\
\hline 90 & Peña de la Sal & & .. & $Q \cdot A G$ \\
\hline 91 & " & & $\ldots$ & NFOI. \\
\hline 92 &, & & $\ldots$ & $\mathrm{CN} \cdots$ \\
\hline 93 & , & & ... & MAMRVS. \\
\hline 94 & " & & ... & - MIM. \\
\hline 95 & Alcolea & $\cdots$ & ... & $\begin{array}{l}\text { OFAMAN. On Samian } \\
\text { ware. }\end{array}$ \\
\hline 96 & & $\cdots$ & ... & $\cdots \mathrm{NN} \cdot \mathrm{IV}^{*} . \quad$ Ct. 135 \\
\hline 97 & Mejia ... & ... & ... & TFANN. \\
\hline 98 &,$\quad \ldots$ & ... & ... & LME. \\
\hline 99 &,$\quad \ldots$ & $\ldots$ & ... & 'TFAN ? \\
\hline 100 & $" \quad \ldots$ & $\ldots$ & ... & TFANN? \\
\hline 101 & Peña de la Sa & & ... & PNN. \\
\hline 102 & , & & ... & STA(cc. $\quad C f .105$ \\
\hline 103 & , & & $\ldots$ & CALIZNF. On body. \\
\hline 104 & $"$ & & ... & - NNSIS. \\
\hline 105 & , & & ... & SLACCT. $\quad C f .102$. \\
\hline 106 & ", & & ... & NIII. \\
\hline $1 \cup 7$ & ", & & $\ldots$ & PNN 年. \\
\hline 108 & ", & & ... & PNNSI. \\
\hline 109 & , & & ... & $\begin{array}{l}\text { QFRS+SS : (2). } \quad C f .51, \\
128 .\end{array}$ \\
\hline 110 & , & & ... & $\mathrm{COR}$ \\
\hline 111 & ", & & $\cdots$ & G $\cdot$ ST. \\
\hline 112 & , & & $\cdots$ & $\mathrm{ST} \cdot \mathrm{P} ?$ \\
\hline
\end{tabular}




\begin{tabular}{|c|c|c|c|c|}
\hline No. & \multicolumn{3}{|c|}{ Where Found. } & \\
\hline 113 & \multicolumn{3}{|c|}{ Lora la Vieja ... } & $\begin{array}{l}\mathrm{L} \cdot \mathrm{V} \cdot \mathrm{TROPH}(2) . C f . \\
C . I . L ., \mathrm{VII}, 1331,115 .\end{array}$ \\
\hline 114 & & & $\ldots$ & ORFS. \\
\hline 115 & Peñaflor & .. & ... & $\mathrm{Q} \cdot \mathrm{FC}(4)$ \\
\hline 116 &, & $\ldots$ & $\ldots$ & $\mathrm{OFC}$ \\
\hline 117 & $"$ & $\cdots$ & $\ldots$ & $\mathrm{O} \cdot \mathrm{T} \cdot \mathrm{V}$ \\
\hline 118 & 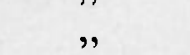 & $\ldots$ & $\ldots$ & CNAC. \\
\hline 119 & , & $\ldots$ & $\ldots$ & DAP. \\
\hline 120 & . & $\ldots$ & $\ldots$ & CIB. \\
\hline 121 & क & $\ldots$ & $\ldots$ & $-7: A$. \\
\hline 123 & Alcolea & $\cdots$ & .. & $\mathrm{L} \cdot \mathrm{Q}$ \\
\hline 124 & , & .. & $\ldots$ & PNN. $\quad C f .81$ \\
\hline 125 & , & .. & .. & MCSP. $C f .80$. \\
\hline 126 & 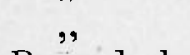 & & $\ldots$ & MMCSV. \\
\hline 127 & Pena de la & & ... & $\mathrm{L} \cdot \mathrm{G} \cdot \mathrm{G}$ \\
\hline 128 & " & & .. & QFRMED (2). Cf. 51, 109. \\
\hline 129 & " & & .. & $\triangle$ ¿I.AZ. $\quad C f .31,63$. \\
\hline 130 & $"$ & & ... & MEDAN. $\quad C f .24$ \\
\hline 131 & " & & ... & $\cdots \mathrm{DED} \cdots ?(2)$ \\
\hline 132 & & & & $\mathrm{OE} \cdots \cdots$ \\
\hline 133 & Guadajoz & $\cdots$ & ... & $\cdots \mathrm{MMF} \cdot \mathrm{D}$. Rest illegible. \\
\hline 134 & ", & & $\cdots$ & q26u? \\
\hline 135 & Huerta del & & $\cdots$ & $\begin{array}{l}\text { III }{ }_{96 N}^{\mathrm{ENN}} \cdot \mathrm{IV} \\
\end{array}$ \\
\hline 136 & ", & & .. & PECS 正N. \\
\hline 137 & & & .. & $\begin{array}{l}\cdots \text { AENI. Cf. C. I. L., } \\
\text { VII, 1331, } 102 ; 12, \\
\text { 5683, 231. }\end{array}$ \\
\hline 138 & " & & .. & 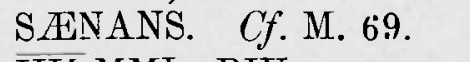 \\
\hline 139 & & & & $\overline{I I I I}$ MMI $\cdot$ RIV. \\
\hline 140 & Maiena & & ... & $\Lambda \mathrm{V} \cdot \mathrm{HR}$ \\
\hline 141 &, & $\ldots$ & ... & $\mathrm{RA} \overline{\mathrm{AN}} ?$ \\
\hline 142 &, & $\ldots$ & $\ldots$ & $\Lambda$ VIHG. \\
\hline 143 & & $\ldots$ & ... & AITA. \\
\hline 144 & Acebucha & $\ldots$ & ... & L・EL. \\
\hline
\end{tabular}


304 THE ROMAN TOWNS IN THE VALLEY OF THE B ETIS,

\begin{tabular}{|c|c|c|c|c|}
\hline No. & \multicolumn{3}{|c|}{ Where Found. } & \\
\hline 145 & Los Villares & & $\ldots$ & AVG. \\
\hline 146 & Belen (Palma) & & $\ldots$ & FORTVNATM. \\
\hline 147 &, & & ... & SX $\cdot$ FRCALR $(\ddot{z})$ \\
\hline 148 & 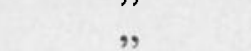 & & $\ldots$ & $\mathrm{F} \cdot \mathrm{S} \cdot \mathrm{F} \cdot \mathrm{A} \cdot \mathrm{QVA} ?$ \\
\hline 149 & " & & $\cdots$ & SAXOFERR (2). \\
\hline 151 & $"$ & & & $\left\{\begin{array}{l}\cdots \text { FERR } \\
\text { EV¥ }\end{array}\right\}=149$. \\
\hline 152 & " & & $\cdots$ & RATuT. \\
\hline 153 & Portillo (Palm & a) & $\cdots$ & $\left.\begin{array}{l}\text { VFNCEPA } \\
\text { CORALODFA }\end{array}\right\} \begin{array}{l}\mathrm{Cf} . \\
\text { Dressel, } \\
\text { p. } 141 .\end{array}$ \\
\hline 155 & Peñaflor & $\cdots$ & .. & - II FF IILV . \\
\hline 156 & & ... & .. & TREPII. \\
\hline 157 & & $\cdots$ & $\cdots$ & NII. \\
\hline 158 & Moratalla & $\cdots$ & ... & POEBI. \\
\hline 159 & Ant. Serrano & ... & .. & CVC $\cdots$ \\
\hline 160 & & $\cdots$ & .. & G DEC $\cdots$ \\
\hline 161 & Guadiato & $\cdots$ & .. & $\mathrm{C} \cdot \operatorname{IVI} \cdot \operatorname{BAR}(4)$ \\
\hline 162 & Villaseca & ... & $\cdots$ & $\mathrm{T} \cdots \mathrm{VA}$ ? \\
\hline 163 & , , & .. & $\cdots$ & $\cdots$ bC $\cdots$ \\
\hline 164 & Est. de la Tor & cronter: & & $\mathrm{G} D E C=160$ \\
\hline 165 & " & & ... & M · IOFI. \\
\hline 166 & & & .. & - FVJว \\
\hline 167 & La Dehesilla & $\cdots$ & .. & LFC $\cdots$ I arge. \\
\hline 168 & , & $\ldots$ & ... & MFVO ... \\
\hline 169 & , & $\cdots$ & $\ldots$ & FSCVFM ? \\
\hline 170 & $"$ & ... & $\ldots$ & LFCCV $\cdots$ \\
\hline 171 & ", & $\cdots$ & ... & - FCCV-FM. \\
\hline 172 & & $\cdots$ & $\cdots$ & GFSCVFM. \\
\hline 173 & Corregidora & $\cdots$ & $\cdots$ & $\left\{\begin{array}{l}\text { FIG ED } \\
\text { PPAEF }\end{array}\right\}+\mathbb{*}(3)$. \\
\hline 174 & $"$ & $\cdots$ & $\cdots$ & \\
\hline $\begin{array}{l}175 \\
176\end{array}$ & Castilleio & $\cdots$ & $\begin{array}{l}\cdots \\
\ldots\end{array}$ & $\begin{array}{l}\text { PM } \cdots \text { large and incuse. } \\
\text { LFCCVF2 (3). }\end{array}$ \\
\hline 177 & Malpica & $\cdots$ & $\cdots$ & $\mathrm{C} \cdot \mathrm{I} \cdot \overline{\mathrm{B}} \cdot \mathrm{SA}$ \\
\hline
\end{tabular}




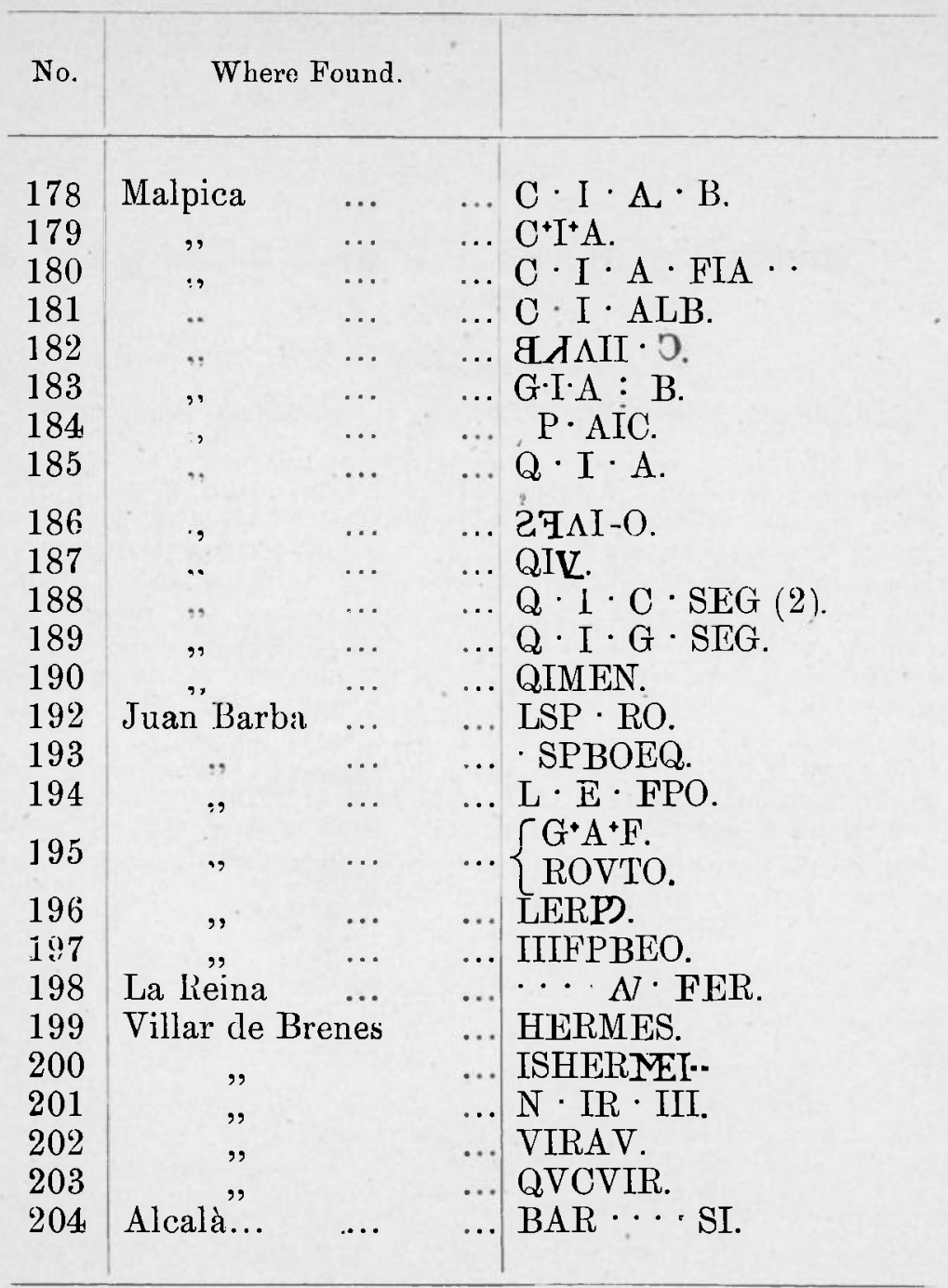

